NBER WORKING PAPER SERIES

A THEORY OF BANKS, BONDS, AND THE DISTRIBUTION OF FIRM SIZE

\author{
Katheryn N. Russ \\ Diego Valderrama \\ Working Paper 15454 \\ http://www.nber.org/papers/w15454
}

\author{
NATIONAL BUREAU OF ECONOMIC RESEARCH \\ 1050 Massachusetts Avenue \\ Cambridge, MA 02138 \\ October 2009
}

The authors thank Paul Bergin, Galina Hale, Bart Hobijn, Mark Spiegel and Robert Vigfusson for helpful suggestions, as well as seminar participants at the Asia-Pacific Economics Association 2009 Summer Meetings, the Federal Reserve Bank of San Francisco, the Federal Reserve Board of Governors, and the International Monetary Fund. They are especially grateful to Martin Bodenstein for a detailed discussion. Hirotaka Miura and Nina Ozdemir provided excellent research assistance. The views expressed herein are those of the authors and do not necessarily reflect those of the Federal Reserve Bank of San Francisco, the Federal Reserve System, or the National Bureau of Economic Research.

NBER working papers are circulated for discussion and comment purposes. They have not been peerreviewed or been subject to the review by the NBER Board of Directors that accompanies official NBER publications.

(C) 2009 by Katheryn N. Russ and Diego Valderrama. All rights reserved. Short sections of text, not to exceed two paragraphs, may be quoted without explicit permission provided that full credit, including (C) notice, is given to the source. 
A Theory of Banks, Bonds, and the Distribution of Firm Size

Katheryn N. Russ and Diego Valderrama

NBER Working Paper No. 15454

October 2009

JEL No. E10,F4,G32,L11,L16

\begin{abstract}
$\underline{\text { ABSTRACT }}$
We draw on stylized facts from the finance literature to build a model where altering the relative costs of bank and bond financing changes the entire distribution of firm size, with implications for the aggregate capital stock, output, and welfare. Reducing transactions costs in the bond market increases the output and profits of mid-sized firms at the expense of both the largest and smallest firms. In contrast, reducing the frictions involved in bank lending promotes the expansion of the smallest firms while all other firms shrink, even as it increases the profitability of both small and mid-size firms. Although both policies increase aggregate output and welfare, they have opposite effects on the extensive margin of production---promoting bond issuance causes exit while cheaper bank credit induces entry. When reducing transactions costs in one market, the resulting increase in output and welfare are largest when transactions costs in the other market are very high.
\end{abstract}

\author{
Katheryn N. Russ \\ Department of Economics \\ University of California, Davis \\ One Shields Avenue \\ Davis, CA 95616 \\ and NBER \\ knruss@ucdavis.edu \\ Diego Valderrama \\ Federal Reserve Bank of San Francisco \\ 101 Market Street \\ MS 1130 \\ San Francisco, CA 94010 \\ Diego.Valderrama@sf.frb.org
}




\title{
A Theory of Banks, Bonds, and the Distribution of Firm Size*
}

\author{
Katheryn N. Russ ${ }^{\dagger}$ \\ University of California, Davis \\ Diego Valderrama ${ }^{\ddagger}$ \\ Federal Reserve Bank of San Francisco
}

August 2009

[THIS VERSION: 10/15/2009]

\begin{abstract}
We draw on stylized facts from the finance literature to build a model where altering the relative costs of bank and bond financing changes the entire distribution of firm size, with implications for the aggregate capital stock, output, and welfare. Reducing transactions costs in the bond market increases the output and profits of mid-sized firms at the expense of both the largest and smallest firms. In contrast, reducing the frictions involved in bank lending promotes the expansion of the smallest firms while all other firms shrink, even as it increases the profitability of both small and mid-size firms. Although both policies increase aggregate output and welfare, they have opposite effects on the extensive margin of production - promoting bond issuance causes exit while cheaper bank credit induces entry. When reducing transactions costs in one market, the resulting increase in output and welfare are largest when transactions costs in the other market are very high.
\end{abstract}

\section{Introduction}

While it is widely accepted that bank and bond market development affect small firms differently, it is not clear how altering the relative costs between different financial instruments affects the allocation of capital and output across firms in general equilibrium. As Beck, Demirgüç-Kunt, Laeven, and Levine (2008) write, "theory stresses the link between financial market imperfections and small firms, not necessarily the link between finance and [the] entire distribution of firm sizes in an economy." We model how the choice between bank and bond financing influences the capital stock, aggregate output, and welfare through the channel of intra-industry reallocation. We find

\footnotetext{
${ }^{*}$ The authors thank Paul Bergin, Galina Hale, Bart Hobijn, Mark Spiegel and Robert Vigfusson for helpful suggestions, as well as seminar participants at the Asia-Pacific Economics Association 2009 Summer Meetings, the Federal Reserve Bank of San Francisco, the Federal Reserve Board of Governors, and the International Monetary Fund. They are especially grateful to Martin Bodenstein for a detailed discussion. Hirotaka Miura and Nina Ozdemir provided excellent research assistance. The views expressed herein are those of the authors and do not necessarily reflect those of the Federal Reserve Bank of San Francisco or the Federal Reserve System.

${ }^{\dagger}$ Department of Economics, One Shields Avenue, Davis, CA 95616, USA. Email: knruss@ucdavis.edu

${ }^{\ddagger}$ Economic Research, 101 Market Street, MS 1130, San Francisco, CA 94105, USA. Telephone: +1 (415) 974-3225. Facsimile: +1 (415) 974-2168. Email: Diego.Valderrama@sf.frb.org.
} 
that looking at the entire distribution of firm sizes is key to assessing the macroeconomic impacts of developing specific types of financial markets and its effect on firm behavior.

We study the interaction between firm financial choice and production using a closed-economy version of a Melitz (2003)/Ghironi and Melitz (2005) model with firm heterogeneity, innovating within this framework by introducing capital investment and two distinct financial markets. By assumption, firms must borrow from financial intermediaries to purchase capital for production. There are two types of contracts available to the firms, intermediated bank loans and public bonds. Bond issuance involves a higher fixed cost than bank loans, which limits access to firms with large sales revenues. The bond yield and interest rate on bank loans are each the result of a costly state verification problem as in Carlstrom and Fuerst (2001). As public debt issues are commonly referred to as "unmonitored" lending, we assume the monitoring cost is lower for bond investors than for bank lenders. Firms find it harder to access the public bond market due to the higher fixed cost; however, in our model, these fixed costs reduce the cost of monitoring firms in the event of default, so the marginal cost of financing capital with bond issues is cheaper than with bank loans - the bond yield is lower than the bank interest rate.

In contrast to studies arguing that financial development favors small firms, our findings indicate that the impacts of policy targeted at one market or the other are much more nuanced. For instance, reducing the spread between the interest rates on bank loans and bank deposits by lowering monitoring costs or through other means, including direct subsidies, ${ }^{1}$ increases the size and the number of small firms operating in our model (the extensive margin), as they depend on bank credit for capital financing. Mid-sized firms induced to switch to bank credit from bond issuance shrink in size. These mid-sized firms enjoy lower fixed costs of financing when switching to bank credit, but pass their increased marginal costs of financing on to consumers in the form of higher prices. The largest firms, bond issuers who continue to issue bonds, also shrink a bit as small firms pass savings in the costs of bank financing to consumers in the form of lower prices and steal away bits of the largest firms' market share. The net effect, due to the expansion of incumbent bank borrowers, is growth in the intensive margin of production for the average firm.

The real wage increases when incumbent bank borrowers lower their prices and expand their

\footnotetext{
${ }^{1}$ Alternatively, increased competition (contestability) in the banking sector might reduce lending to deposit rate spreads, which would have an equivalent effect in our stylized framework. See Claessens and Laeven (2004) for empirical evidence and de Blas and Russ (2009) for a theoretical model of contestability and spreads.
} 
output. Notably, this increase in labor costs diminishes the profits of the largest firms, including some of the mid-sized firms that switch to bank financing. Further, despite the switching of some firms from bond issues to bank credit when bank monitoring costs fall, the increase in the relative cost of labor among bond issuers actually increases total bond issuance, as these large firms substitute capital for labor. This second-order complementarity generates a "co-evolution in banks and [bond] markets," described by Levine (2005) as an important feature of financial development.

This co-evolution breaks down when financial policy targets transactions costs in the bond market. In our model, policies that reduce the fixed cost of bond issuance, like policies that reduce bank monitoring costs, have a positive aggregate impact, increasing the overall capital stock, output, and welfare. However, reducing bond issuance costs squeezes the extensive margin of production. As the bond issuance cost falls, mid-sized firms switch from bank to bond issues. These switching firms benefit from a reduction in marginal costs as bond issuance is cheaper, on the margin, than bank borrowing, which allows them to lower their prices and spurs them to increase output, driving up the real wage. Incumbent bank borrowers both lose market share to the price-cutting switchers and struggle with higher labor costs, forcing some to exit and survivors to shrink. As with the bank-promoting policy, a reduction in bond issuance costs also increases the intensive margin of production for the average firm. However, in this case, the cheaper prices charged by these switching mid-sized firms usurps market share from the largest firms that did not switch from bank borrowing to bond issuance. These large firms reduce their output, just like the surviving bank borrowers. New bond issues by the switchers outweigh cutbacks by incumbent bond issuers, so total bond issues increase, even as the banking sector contracts.

Government policies play an important role in determining the fixed issuance costs and the monitoring costs that we model. The improvement of institutions such as bankruptcy courts and contract enforcement reduces the burden of monitoring costs for banks, improving their efficiency as intermediaries and potentially lowering their interest rates on loans. Endo (2008) finds that government policies can also pose substantial barriers to entry into the bond market. Our model suggests that the gains from policies targeted at reducing any transactions costs like these depend on the level of transactions costs in other sectors of the financial market. The relative gains from bond development are largest when the interest rates on bank loans are high, as bond sector development helps circumvent the distortions caused by bank inefficiency. Similarly, the gains from 
banking sector development are also the greatest when the fixed cost involved in bond issuance is high. Thus, the effect of any policy aimed at financial development depends on the full menu of financial choices available to firms.

\subsection{Key assumptions and empirical evidence}

We are agnostic as to which types of institutions might be best overall for financial development, growth and welfare. ${ }^{2}$ Instead, we asses the interaction between the most basic features of domestic banking and bond markets and their implications for the distribution of firm size and economic welfare. To this end, we present empirical support for our key assumptions - a higher fixed cost and lower marginal cost for bond versus bank financing.

We assume that there is a sizeable fixed cost involved in public issues of corporate bonds, which results in large firms issuing bonds in public debt markets and smaller firms using bank loans for credit. Krishnaswami, Spindt, and Subramaniam (1999) find that all but the largest U.S. firms are shut out of public debt markets by large issuance costs. Zervos (2004) calculates that costs of issuing domestic corporate debt range between $2 \%$ and $4.8 \%$ of the size of issues in Latin America. Data on fixed fees associated with bank loans are sparse, but a survey of loan and issuance fees discussed in our Calibration section suggests that they are about half the size of those associated with primary bond issues in the United States. A novel survey by Leal and Carvalho-da Silva (2006) of 357 firms listed on the Brazilian stock exchange reveals that high issuance costs are the number one impediment to bond issuance, with underwriting fees, credit rating agencies' fees, lawyers' fees, registration fees, and disclosure requirements cited as significant obstacles to issuance by $23-43 \%$ of firms surveyed. ${ }^{3}$ Hale and Santos (2008) present evidence that the large fixed cost involved in floating public bonds for the first time is likely to be a mechanism to help overcome information asymmetries, as issuing public debt lowers the spreads firms pay in other credit markets. They also note that more than $80 \%$ of firms that issue public debt had no official credit rating until the time of the issue. Thus, it is reasonable to assume that fixed costs of bond issuance are large and associated with a low monitoring cost for bondholders, which is the parameter representing

\footnotetext{
${ }^{2} \mathrm{~A}$ vast body of work reviews the role that financial development has on growth. This literature has been surveyed extensively by Levine (1997, 2005). Levine (2005) points out that the structure of the financial system (bank-based versus market-based) is not a good predictor of financial development as measured by overall access to and levels of private credit. See Demirgüç-Kunt and Maksimovic (2002) for detailed discussion of this finding.

${ }^{3}$ See Appendix 2, question d on p.75 in Leal and Carvalho-da Silva (2006) for these findings.
} 
information asymmetries in our model.

Large fixed costs in our model mean that only the largest, most profitable firms issue bonds. Mizen and Tsoukas (2008) show that bond issuers are approximately 10-15\% larger than non-issuers in Indonesia, South Korea, Malaysia, and Thailand, though their evidence associating issuance with profitability is mixed. Denis and Mihov (2003) demonstrate that borrowers in U.S. public debt markets are larger, more profitable, and have higher credit ratings, while smaller firms use banks or privately placed debt. Both Houston and James (1996) and Johnson (1997) report bank debt being concentrated among smaller U.S. firms, even though they use samples taken from pools of large, publicly traded companies, so that their smaller firms are more "medium-sized."

We also assume that bond investors have to pay lower monitoring costs than banks once a firm defaults. In the event that a firm defaults, the larger issuance cost allows investors to recoup their investment with lower monitoring costs than would occur with bank loans. ${ }^{4}$ The small fixed costs incurred when using bank loans means the firm remains less transparent to lenders, so that banks must incur additional monitoring costs to recover their funds in the event that a borrower defaults. Is this assumption reasonable? The higher bank monitoring cost translates into higher interest rates charged by banks than are paid on bonds. Indeed, this is true on average. Though yields may be higher or lower than the prime rate at any given time, since 1949 the yield for Moody's seasoned Aaa bonds has been an average of 16 basis points higher than the bank prime rate. ${ }^{5}$ Further, in the survey by Leal and Carvalho-da Silva (2006), zero respondents cited high interest rates as an impediment to bond financing, while $90 \%$ cited high interest rates as an impediment to borrowing from domestic banks and 33\% cited them as problematic when borrowing from foreign banks. Though there is no comparable question regarding monitoring for bond issues, $13 \%$ of respondents reported that monitoring by banks was a problem when using domestic bank loans and $17 \%$ when using foreign bank loans. Thus, it is quite plausible that interest rates are higher for bank loans than bond issues, even among the largest, least risky borrowers - especially those with no agency credit ratings, given the results in Hale and Santos (2008) - and that monitoring costs are likely

\footnotetext{
${ }^{4}$ For the sake of simplicity — and without loss of generality — we presume the monitoring cost for firms defaulting on bond issues is zero, though it can still be positive for our results to hold. It need only be lower than the monitoring cost for bank loans in default, in accordance with the appellation "unmonitored" lending, which is often applied to bond markets.

${ }^{5}$ Moody's Seasoned Aaa Corporate Bond Yield minus the Bank Prime Loan Rate, Federal Reserve Board of Governors Release H.15 Selected Interest Rates (1/1/1949-7/1/2009, monthly), downloaded from the Federal Reserve Bank of St. Louis FRED database.
} 
generating part of that spread.

Most importantly, the results on bank versus bond market development and firm size are consistent with more general results regarding financial development. A number of studies using firm-level data ${ }^{6}$ show that financial underdevelopment disproportionately impacts access to credit for small- and medium-sized firms. Most recently, Beck, Demirgüç-Kunt, Laeven, and Levine (2008) discover that small-size firms are more prevalent in the manufacturing output of countries with higher levels of financial development. Presenting new empirical support, they argue that financial development increases access to credit for small firms and expands credit for firms that already have access: financial development increases the supply of credit on both the extensive and the intensive margin. We can capture this result. We show that for both margins to expand at once, there must be improvements in bank efficiency which we model here as reduced monitoring costs, though the increase in bank efficiency could be due to be any type of technological improvement or subsidy in the banking sector or strengthening of the legal structure that reduces spreads between bank lending and deposit rates.

In the interests of tractability, we assume that the risk of default is the same for bond issuers and bank borrowers and is not correlated with firm size. This nontrivial simplification is not directly contradicted by the data, but has at best weak support. (Altman and Suggitt, 2000) show that the marginal default rate for syndicated loans versus bond issues are very similar in the first three years and almost identical at three- to five-year horizons. It is difficult to assess precisely what the default rate is on the universe of non-syndicated commercial bank loans. ${ }^{7}$ However, data on default by small businesses requiring government loan guarantees (presumably the most speculative of small business ventures) show rates of loan default that are almost identical to those of (large) public debt issuers rated "speculative" (Glennon and Nigro, 2005). Thus, although the default rate may well be correlated with firm size, it is not immediately clear that the default rates differ for public bond issues versus bank loans conditional on firm size. All previous theoretical studies discussed below assume or obtain a result where the default rate is lower for bond issuers than bank borrowers, which ends up being observationally equivalent in our model to the assumption that monitoring

\footnotetext{
${ }^{6}$ See Benfratello, Schiantarelli, and Sembenelli (2008) (in particular, their fantastic footnotes 1-3) and Beck, Demirgüç-Kunt, Laeven, and Levine (2008) for surveys.

'We can not use the plentiful data on nonperforming loan ratios, as these are akin to stock variables, while the default rate is a flow variable. Estimates of the default rate tend to be much lower than the gross firm exit rate, which is measured precisely for the U.S., so the exit rate is not an appropriate proxy, either.
} 
costs are lower for bond issuers. Further, the assumption of an exogenous exit shock uncorrelated with firm size is a helpful convention in seminal studies focusing on firm heterogeneity such as Melitz (2003) and Ghironi and Melitz (2005) and we apply it to the default rate in this spirit.

\subsection{Theoretical literature on financial choice}

A deep and venerable literature models the choice between financial instruments. To model the marginal cost of financing, we use the costly state verification used to overcome information asymmetry in Carlstrom and Fuerst (2001), which is drawn from the work of Townsend (1979). In the Carlstrom and Fuerst (2001) framework, firms must borrow some proportion of their working capital from financial intermediaries. The precise amount depends on their net worth carried over from previous periods, so the dynamic component is quite important. The default rate in their setup is endogenous, a function of the information asymmetry, but in their model and ours, all firms have the same probability of default ex ante. Idiosyncratic productivity shocks that lead to defaults strike each firm, with all shocks drawn from an identical distribution. Intermediaries must monitor firms that default to verify their productivity draw and recover remaining assets. We abstract from dynamics as much as possible to focus on intra-firm reallocation as a channel for financial market development to affect aggregate outcomes. We also assume that firms are heterogeneous in their

efficiency levels ex ante and are struck not by a range of productivity shocks, but by a uniformly distributed exit shock. The exit shock prevents the firm from producing, so the intermediary that lent it capital at the beginning of the period can only recoup the capital itself, minus any monitoring costs and without any accrued interest. We also introduce a fixed cost into the loan contract, which is added to the value of the loan principal or bond issue and paid (with interest if a firm does not default) after production and sales take place. Thus, the fixed cost affects the decision to borrow, but not the marginal cost of capital.

The setup differs from Diamond (1991) who assumes that firms differ in their probability of default ex ante. In Diamond (1991), the choice between bank and bond financing is a process of sorting good from bad firms, or verifying the behavior of unreliable middle-ranked firms who might choose good or bad projects. The best firms are able to develop a reputation for credit worthiness that qualifies them for unmonitored lending through bond issues. We assume that there is no difference between the potential for bond issuers and bank borrowers to default. However, the time 
it takes to develop a strong reputation could be considered a large fixed cost and our results all hold even if bond issuers do have a lower incidence of default, as that reduces the bond yield relative to the interest rate on bank loans. Our key assumptions therefore are generally complementary with the underlying mechanisms in the Diamond (1991) model, even though we do not involve dynamic reputation effects and do not presume different default rates across borrowers.

Holmstrom and Tirole (1997) and Repullo and Suarez (1998, 2000) assume that firms are heterogeneous in their initial endowment of assets when deciding between monitored and unmonitored sources of finance. Holmstrom and Tirole (1997) focus on the macroeconomic effects of exogenous shocks to entrepreneurial or bank capital, similar to Carlstrom and Fuerst (1997), while Repullo and Suarez (2000) analyze the impact of exogenous shocks to the market interest rate due to changes in monetary policy. Both Holmstrom and Tirole and Repullo and Suarez produce the general result that the firms with the greatest net worth use direct (bond) finance, while firms with lesser net worth use banks and those with the lowest net worth can not secure external financing at all. ${ }^{8}$ We assume that all cash flows are rebated to the consumer as dividends at the end of each period, so firms do not use retained earnings to finance their working capital as in these models (or, indeed, as in Carlstrom and Fuerst (2001)). Financing investment with retained earnings is an interesting and realistic feature of the dynamic behavior of firms responding to fluctuations in macroeconomic conditions. However, we elect to focus on the allocation of production across heterogeneous firms in steady state. In a steady-state equilibrium, it is reasonable to imagine firms being required to remit almost all profits to shareholders, rather than sitting on stores of cash. Nonetheless, in our model the most technologically efficient firms also end up with the highest net worth in each period and use bond issues to finance their capital, while less efficient firms have a lower net worth and use bank loans, with the least efficient firms not producing at all. So these general results are consistent with past work, even while we focus on intra-industry reallocation across steady states rather than dynamic responses to aggregate shocks. We also innovate by endogenizing the size of capital investment and let it vary by firm and by the marginal cost of financing, so the presence of financial choice increases dispersion in firm size.

The models closest to ours look at different types of financial choice in general equilibrium

\footnotetext{
${ }^{8}$ Firms with lower net worth require monitoring because they have a higher probability of default. Firms with the lowest net worth have such a high probability of default that the cost of necessary monitoring outweighs the potential payoffs from production.
} 
that encompass the general properties of monitored versus unmonitored lending. De Fiore and Uhlig (2005) examine the substitution between bank lending and trade credit, where trade credit forces the liquidation of the entire firm in the event of default, while bank borrowing involves only monitoring. Firms are heterogeneous due to an idiosyncratic productivity shock at the beginning of the period. Their goal is to explain the prevalence of bank financing in Europe relative to the U.S. We use a simplified stochastic framework and employ fixed costs of financing to analyze the implications of policies that favor the development of a particular financial market for distribution of output across heterogeneous firms and the resulting aggregate effects. In this sense, our setup is more similar to Ghironi and Lewis (2008), who analyze heterogeneous firms' choice of whether to become publicly listed on a stock exchange. Listing invites the monitoring of stockholders. Their model actually allows this financing choice to affect the efficiency of firm managers, who become more efficient under the scrutiny of equity investors. We stay rooted in the more basic costly stateverification from Carlstrom and Fuerst (2001), where monitoring costs affect payoffs to lenders, but not firm governance.

Section 2 describes the model of firms and intermediaries. Section 3 discusses the calibration. Section 4 solves the model and shows the macroeconomic effects of banking sector and bond market development through the channel of firm-level financing decisions. Section 5 concludes and offers ideas for future research.

\section{Studying the interaction between financial structure and real activity}

In this section, we build a closed economy model of banks, bonds, and heterogeneous firms. Domestic households consume and provide labor and capital to firms. They also own all domestic firms and receive profits from these firms. The final goods sector is competitive and aggregates imperfectly substitutable intermediate goods to produce final goods. Intermediate goods producers hire labor and rent capital from households through financial intermediaries. Depending on whether they issue domestic public debt or take out loans from banks, they will pay different fixed and marginal costs. Intermediate goods producers use identical technologies and only differ in their level of idiosyncratic efficiency when transforming labor and capital into varieties of the intermedi- 
ate good. Financial intermediaries channel savings from households to domestic firms. As discussed above, banks charge a low fixed cost to set up a financial contract but must monitor more closely firms that default and thus charge a high markup over their cost of funds to cover the monitoring costs. Firms that issue public bonds pay a large fixed fee to reveal information that reduces the monitoring costs involved for bond investors. We make standard assumptions regarding the distribution of idiosyncratic efficiency levels across firms that allow us to aggregate factor demands and an endogenous split between the behavior of bank borrowers and public bond issuers.

\subsection{Households}

The representative domestic household maximizes discounted lifetime utility with respect to consumption and labor supply,

$$
\max _{C_{t}, c(i)_{t}, L_{t}, K_{t+1}^{S}} \sum_{t=0}^{\infty} \beta^{t} U\left(C_{t}, L_{t}\right),
$$

where

$$
U\left(C_{t}, L_{t}\right)=\frac{1}{1-\theta}\left(C_{t}-\frac{L_{t}^{\psi}}{\psi}\right)^{1-\theta}
$$

$L_{t}$ is the amount of labor supplied and $C_{t}$ represents aggregate consumption of a homogeneous final good. The instantaneous utility function (2.1) is of the form suggested by Greenwood, Hercowitz, and Huffman (1988) (GHH). It eliminates the wealth effect on the labor supply so that it directly depends only on the wage rate and not on the level of consumption or the interest rate.

The consumer maximizes lifetime utility subject to the budget constraint:

$$
P_{t} Y_{t}=P_{t} C_{t}+P_{t} K_{t+1}^{S}=w_{t} L_{t}+r_{t} P_{t} K_{t}^{S}+P_{t} K_{t}^{S}(1-\gamma)+\pi_{t}^{I}+\pi_{t}^{F}
$$

where $w_{t}$ is the wage rate, $r_{t}$ is the rental rate, $K_{t}^{S}$ is the capital (savings) supplied by the household to firms through financial intermediaries, $\pi_{t}^{I}$ and $\pi_{t}^{F}$ are dividends paid by financial intermediaries and firms to households. Capital depreciates at rate $\gamma \cdot{ }^{9}$ Given the GHH preferences, the first order

\footnotetext{
${ }^{9}$ We note that the capital accumulation equation, $I_{t}=K_{t+1}-(1-\gamma) K_{t}$, yields an equivalent form for the budget constraint, $P_{t} Y_{t}=P_{t} C_{t}+P_{t} I_{t}=w_{t} L_{t}+r_{t} P_{t} K_{t}+\pi_{t}^{I}+\pi_{t}^{F}$.
} 
condition with respect to labor yields the usual labor supply equation:

$$
L_{t}^{S}=\left(\frac{w_{t}}{P_{t}}\right)^{\frac{1}{\psi-1}}
$$

The first order condition with respect to aggregate consumption, $C_{t}$, equates the Lagrange multiplier on the resource constraint $2.2, \lambda_{t}$, with the price adjusted marginal utility of consumption:

$$
\lambda_{t} P_{t}=\left(C_{t}-\frac{L_{t}^{\psi}}{\psi}\right)^{-\theta}
$$

The first order condition with respect to capital is given by

$$
\lambda_{t} P_{t}=\beta \lambda_{t+1} P_{t+1}\left(r_{t+1}+1-\gamma\right)
$$

Substituting the lagrange multiplier from (2.4) into the first order condition 2.5 yields the usual intertemporal Euler equation:

$$
\frac{\left(C_{t}-\frac{L_{t}^{\psi}}{\psi}\right)^{-\theta}}{\beta\left(C_{t+1}-\frac{L_{t+1}^{\psi}}{\psi}\right)^{-\theta}}=1+r_{t+1}-\gamma
$$

This expression equates the intertemporal marginal rate of substitution (on the left hand side) with the gross return to capital after accounting for depreciation (on the right hand side).

Implicit in this expression is the assumption that capital goods can be transformed one-for-one from the aggregated consumption bundle.

\section{$2.2 \quad$ Final goods producers}

The time subscripts above are necessary to address the consumer's intertemporal reallocation that results in savings. For simplicity, we drop the time subscripts in our discussion of firms here. A perfectly competitive industry produces $Y$, a final good used for consumption and investment in the capital stock, by assembling a continuum of differentiated intermediate goods on the interval 
$(0, N)$ using the constant elasticity of substitution (CES) production technology,

$$
Y=\left(\int_{0}^{N} y(i)^{\frac{\sigma-1}{\sigma}} d i\right)^{\frac{\sigma}{\sigma-1}}
$$

For simplicity, we assume that this assembly process requires only the intermediate goods-no additional labor or capital. Different varieties $i$ of each intermediate good, $y(i)$, have an associated price level, $p(i)$. Define the total expenditure on intermediate goods as follows:

$$
P Y=\int_{0}^{N} p(i) y(i) d i
$$

The CES production structure yields the standard cost-minimizing price index $P$ :

$$
P=\left(\int_{0}^{N} p(i)^{1-\sigma} d i\right)^{\frac{1}{1-\sigma}}
$$

Demand for a particular variety $i$ of the intermediate good is given by

$$
y(i)=\left(\frac{p(i)}{P}\right)^{-\sigma} Y
$$

which is downward sloping in its price, $p(i)$.

\subsection{Intermediate goods producers}

A mass of firms intermediate goods make production and financing decisions to maximize profits. Each firm producing intermediate goods hires labor and borrows to purchase capital at the beginning of the period to manufacture its unique variety. Each firm must also decide whether to finance its capital expenditures by obtaining bank loans or issuing public bonds. As we discuss later, each type of financial contract entail a fixed cost and a marginal cost: the interest rate $r_{j}$ and the fixed cost $f_{j}$. The fixed costs for issuing public bonds $f_{b}$ is greater than the fixed cost to obtain a bank loan, $f_{l}$. The marginal cost of bond credit, $r_{b}$ is lower than the marginal cost of a bank loan, $r_{l}$. All workers in the economy receive the same wage rate, $w$. Firms take as given the wage rage, $w$, the interest rate paid on borrowed capital, $r_{j}$, and the fixed costs of financial contracts, $f_{j}$. 
Each firm produces its unique variety of the intermediate good using the technology

$$
y_{j}(\varphi)=\varphi L_{j}(\varphi)^{\alpha} K_{j}(\varphi)^{1-\alpha}
$$

where $\varphi$ is a firm-specific efficiency parameter, $A$ is a country-specific efficiency parameter, $L(\varphi)$ and $K(\varphi)$ represent the amount of labor and capital used, and $\alpha$ is the share of labor in variable production costs, and the subscript $j$ denotes what type of financing the firm uses: bank loans $(l)$ or bond issues $(b)$. Cost minimization yields conditional demand functions for labor and capital:

$$
\begin{aligned}
L_{j}^{*}(\varphi) & =\left[\left(\frac{1-\alpha}{\alpha}\right) \frac{w}{r_{j}}\right]^{\alpha-1} \frac{y_{j}(\varphi)}{\varphi} \\
K_{j}^{*}(\varphi) & =\left[\left(\frac{1-\alpha}{\alpha}\right) \frac{w}{r_{j}}\right]^{\alpha} \frac{y_{j}(\varphi)}{\varphi}
\end{aligned}
$$

where $r_{j}$ is the firm specific cost of capital and $w$ is the competitive wage rate paid to labor.

\subsection{Marginal costs and pricing}

We define $W_{j}$ as the cost of the cost-minimizing input bundle per unit of output given efficiency level $\varphi$ :

$$
W_{j} \equiv \frac{w^{\alpha} r_{j}^{1-\alpha}}{(1-\alpha)^{1-\alpha} \alpha^{\alpha}} .
$$

We will show below that firms obtaining credit by issuing bonds pay an interest rate, $r_{b}$, that is lower than the interest rate for firms obtaining credit that obtain bank loans, $r_{l}$. Given this feature of the credit markets, firms using bonds have lower marginal costs than firms using bank loans:

$$
W_{l}=\frac{w^{\alpha} r_{l}^{1-\alpha}}{(1-\alpha)^{1-\alpha} \alpha^{\alpha}}>W_{b}=\frac{w^{\alpha} r_{b}^{1-\alpha}}{(1-\alpha)^{1-\alpha} \alpha^{\alpha}} .
$$

A firm with an efficiency parameter $\varphi$ facing fixed financial costs $f_{j}$ sets prices in order to maximize profit,

$$
\pi_{j}(\varphi)=p_{j}(\varphi) y_{j}(\varphi)-\frac{W_{j}}{\varphi} y_{j}(\varphi)-\left(1+r_{j}\right) P f_{j}
$$

The fixed financial costs, denominated units of the final good, and the rental rate on capital depend on the choice of financial instrument that the firm chooses to use. 
To simplify the intermediary's problem, described below, we assume that fixed costs are added into the loan principal or the total amount of the bond issue and paid with interest after sales take place. The fixed cost for bond issuers represents the cost of auditing and underwriting by investment banks, as well as extra reporting necessary to comply with regulatory oversight. ${ }^{10}$ For bank borrowers, the fixed cost involves closing costs or other fees involved with administrating the loan application. We discuss the relative size of these costs and the impact that the choice of financing has on the rental rate of capital for particular firms below.

The firm takes as given market demand for its own variety, equation (2.8). The profit maximization problem yields the standard result that prices are then a constant markup over marginal cost,

$$
p_{j}(\varphi)=\frac{\sigma}{\sigma-1} \frac{W_{j}}{A \varphi}
$$

As in Melitz (2003), more efficient (higher $\varphi$ ) firms charge lower prices. The downward-sloping demand curves imply that firms charging lower prices produce more and have higher revenues.

Given the expression for prices, equation (2.9), we can write an expression for profits as a function of prices, aggregate output, and parameters:

$$
\pi_{j}(\varphi)=\frac{1}{\sigma}\left(\frac{p_{j}(\varphi)}{P}\right)^{1-\sigma} P Y-\left(1+r_{j}\right) P f_{j}
$$

Profits are a positive function of revenues. For a given fixed cost, more productive firms are also more profitable relative to other firms within the industry.

It is immediately clear that firms using loans, which have higher marginal costs, charge higher prices, passing their higher marginal costs onto customers, than they would charge if they had issued public debt. That is,

$$
p_{l}(\varphi)>p_{b}(\varphi)
$$

Since demand and revenues are falling in a variety's price, it follows that sales and variable profits are lower for firms using bank credit.

\footnotetext{
${ }^{10}$ In fact, some portion of the fixed costs of bond issuance are often absorbed in the total amount of capital raised during the underwriting process as part of the "gross fee" when underwriters purchase bonds from the issuer and sell them at a higher price to investors.
} 


\subsection{Credit markets}

Whereas labor wages can be paid at the end of the period when sales occur, firms must borrow funds to pay for capital in advance of production. We posit that firms must pay a large fixed cost to issue bonds, $f_{b}$, paying an interest rate $r_{b}$. To avoid these fees, firms can take out a loan from a bank, paying only a small fixed cost, $f_{l}<f_{b}$, but a higher interest rate, $r_{l}>r_{b}$. We use the mnemonic index $l$ to denote variables pertaining to financing through bank loans and the index $b$ for variables pertaining to financing through publicly issued bonds.

There are two reasons that banks could charge a higher interest rate. The first is that the banking sector is not perfectly competitive, so that $r_{l}$ includes a markup over the deposit rate, which is the cost of funds for banks. This can occur in the absence of any uncertainty or information asymmetries on the part of lenders. The second involves information uncertainties and would arise as a result of an optimal contract. In this case, there is some uncertainty involving firm-specific productivity shocks. The high fixed cost involved in issuing bonds would make the actualization of this shock transparent to lenders, so there is no risk of strategic default on the part of the firm. A bank instead monitors the borrowing firm itself, adding the cost of this monitoring to the rate of interest it charges the borrower. Either way, we have a wedge between the bank lending rate and the deposit rate or bond yield.

Both the marginal cost of financing and the choice of credit instrument is endogenous in this model. We can determine which credit instrument a firm will choose by evaluating the firm's profit function,

$$
\pi(\varphi)=\max \left\{0, \pi_{b}(\varphi), \pi_{l}(\varphi)\right\}
$$

where

$$
\begin{aligned}
& \pi_{b}(\varphi)=p_{b}(\varphi) y_{b}(\varphi)-\frac{W_{b}}{A \varphi} y_{b}(\varphi)-\left(1+r_{b}\right) P f_{b} \\
& \pi_{l}(\varphi)=p_{l}(\varphi) y_{l}(\varphi)-\frac{W_{l}}{A \varphi} y_{l}(\varphi)-\left(1+r_{l}\right) P f_{l}
\end{aligned}
$$

Using the intermediate goods demand function (2.8), profits for firms issuing bonds, $\pi_{b}$, can be reduced to a function of revenues, the fixed cost, and the elasticity of substitution. Both of these 
profit functions are monotonically increasing in $\varphi$,

$$
\begin{aligned}
\frac{\partial \pi_{b}(\varphi)}{\partial \varphi} & =\frac{\sigma-1}{\sigma}\left(\frac{\frac{\sigma}{\sigma-1} \frac{w^{\alpha}}{(1-\alpha)^{1-\alpha} \alpha^{\alpha}}}{P}\right)^{1-\sigma} r_{b}^{(1-\alpha)(1-\sigma)} P Y \varphi^{\sigma-2}>0 \\
\frac{\partial \pi_{l}(\varphi)}{\partial \varphi} & =\frac{\sigma-1}{\sigma}\left(\frac{\frac{\sigma}{\sigma-1} \frac{w^{\alpha}}{(1-\alpha)^{1-\alpha} \alpha^{\alpha}}}{P}\right)^{1-\sigma} r_{l}^{(1-\alpha)(1-\sigma)} P Y \varphi^{\sigma-2}>0 .
\end{aligned}
$$

The relative size of their derivatives depends only on the bond yield or borrowing rate a firm must pay for financing,

$$
\frac{\frac{\partial \pi_{b}(\varphi)}{\partial \varphi}}{\frac{\partial \pi_{l}(\varphi)}{\partial \varphi}}=\frac{r_{l}^{(1-\alpha)(\sigma-1)}}{r_{b}^{(1-\alpha)(\sigma-1)}}
$$

Due to the monitoring cost, this ratio is greater than one: the profit function for bond issuers increases more rapidly in $\varphi$ than the profit function for bank borrowers.

To assess the firm's decision between the two sources of financing, we find two critical firm efficiency levels, one where a firm is indifferent between not producing and producing using loan financing, $\varphi_{l}$, and a second where a firm is indifferent between producing using loan financing and bond financing, $\varphi_{b}$. To obtain the efficiency level of the least efficient active firm, $\varphi_{l}$, we use use the zero profit condition for firms that finance using loans, solving the equation

$$
\pi_{l}\left(\varphi_{l}\right) \equiv 0
$$

This yields a somewhat reduced expression,

$$
\varphi_{l}=\frac{\sigma}{\sigma-1} \frac{1}{(1-\alpha)^{1-\alpha} \alpha^{\alpha}} \frac{w^{\alpha} r_{l}^{1-\alpha}}{P}\left(\frac{\sigma\left(1+r_{l}\right) f_{l}}{Y}\right)^{\frac{1}{\sigma-1}} .
$$

To obtain the efficiency level of the marginal firm that is indifferent between issuing bonds and obtaining bank loans, $\varphi_{b}$, we set the profit earned using bank financing equal to profit earned using bond financing $\left(\pi_{b}\left(\varphi_{b}\right)=\pi_{l}\left(\varphi_{b}\right)\right)$ and obtain:

$$
\varphi_{b}^{\sigma-1}=\frac{\sigma\left[\left(1+r_{b}\right) f_{b}-\left(1+r_{l}\right) f_{l}\right]\left(\frac{\frac{\sigma}{\sigma-1} \frac{w^{\alpha}}{(1-\alpha)^{1-\alpha} \alpha \alpha}}{P}\right)^{\sigma-1}}{Y\left(r_{b}^{(1-\alpha)(1-\sigma)}-r_{l}^{(1-\alpha)(1-\sigma)}\right)} \quad\left(\text { for } r_{b} \neq r_{l}\right)
$$


This threshold level is not identified for $r_{b}=r_{l}$, in which case all firms would simply choose the type of financing with the lowest fixed cost (i.e., bank loans).

We can now derive the condition that guarantees that bond issuers are larger than bank borrowers, $\varphi_{b}>\varphi_{l}$, matching the empirical findings in the finance literature. Since we use a zero profit condition to find $\varphi_{l}$, we require that profit be positive at the efficiency level where firms are indifferent between turning to banks and bonds. Substituting $\varphi_{b}^{\sigma-1}$ into the profit function $\pi_{l}$, we have

$$
\begin{aligned}
\pi_{l}\left(\varphi_{b}\right) & =\frac{1}{\sigma}\left[\left(\frac{\sigma}{\sigma-1}\right) w^{\alpha} r_{l}^{1-\alpha}\right]^{1-\sigma} P^{\sigma} Y\left[\frac{\sigma\left[\left(1+r_{b}\right) f_{b}-\left(1+r_{l}\right) f_{l}\right]\left(\frac{\frac{\sigma}{\sigma-1} w_{l}^{\alpha}}{P}\right)^{\sigma-1}(P Y)^{-1}}{r_{b}^{(1-\alpha)(1-\sigma)}-r_{l}^{(1-\alpha)(1-\sigma)}}\right]-\left(1+r_{l}\right) P f_{l} \\
& =P\left[\frac{r_{l}^{(1-\alpha)(1-\sigma)}\left[\left(1+r_{b}\right) f_{b}-\left(1+r_{l}\right) f_{l}\right]}{\left.r_{b}^{(1-\alpha)(1-\sigma)}-r_{l}^{(1-\alpha)(1-\sigma)}-\left(1+r_{l}\right) f_{l}\right]}\right.
\end{aligned}
$$

which is greater than zero whenever the fixed cost of bond issuance is sufficiently large. The condition that $\pi_{l}\left(\varphi_{b}\right)$ is greater than zero reduces to

$$
f_{b}>\left(\frac{r_{l}}{r_{b}}\right)^{(1-\alpha)(\sigma-1)}\left(\frac{1+r_{l}}{1+r_{b}}\right) f_{l}
$$

Thus, the bond issuers will always be larger and more efficient than bank borrowers when the issuance fee is large relative to the costs of bank intermediation, as shown in Figure 1.

\section{Default and firm death}

We now consider the firm's cost of capital, $r_{j}$ (for $j \in b, l$ ). There is a uniform probability, $0<\delta<1$, that a firm will be hit by an exogenous "death" shock: it's revenues will be zero and the firm will exit without producing. The death shock could arise from an extreme taste shock or some calamity of management exogenous to the model. We model it in such a stark form, in the manner of Melitz (2003) and Ghironi and Melitz (2005), for simplicity. Lenders must audit defaulting firms to verify that they actually received an adverse shock and then appropriately liquidate remaining assets, which involves a monitoring cost. Lenders can recover any borrowed capital from exitors, less monitoring cost and with no interest. 


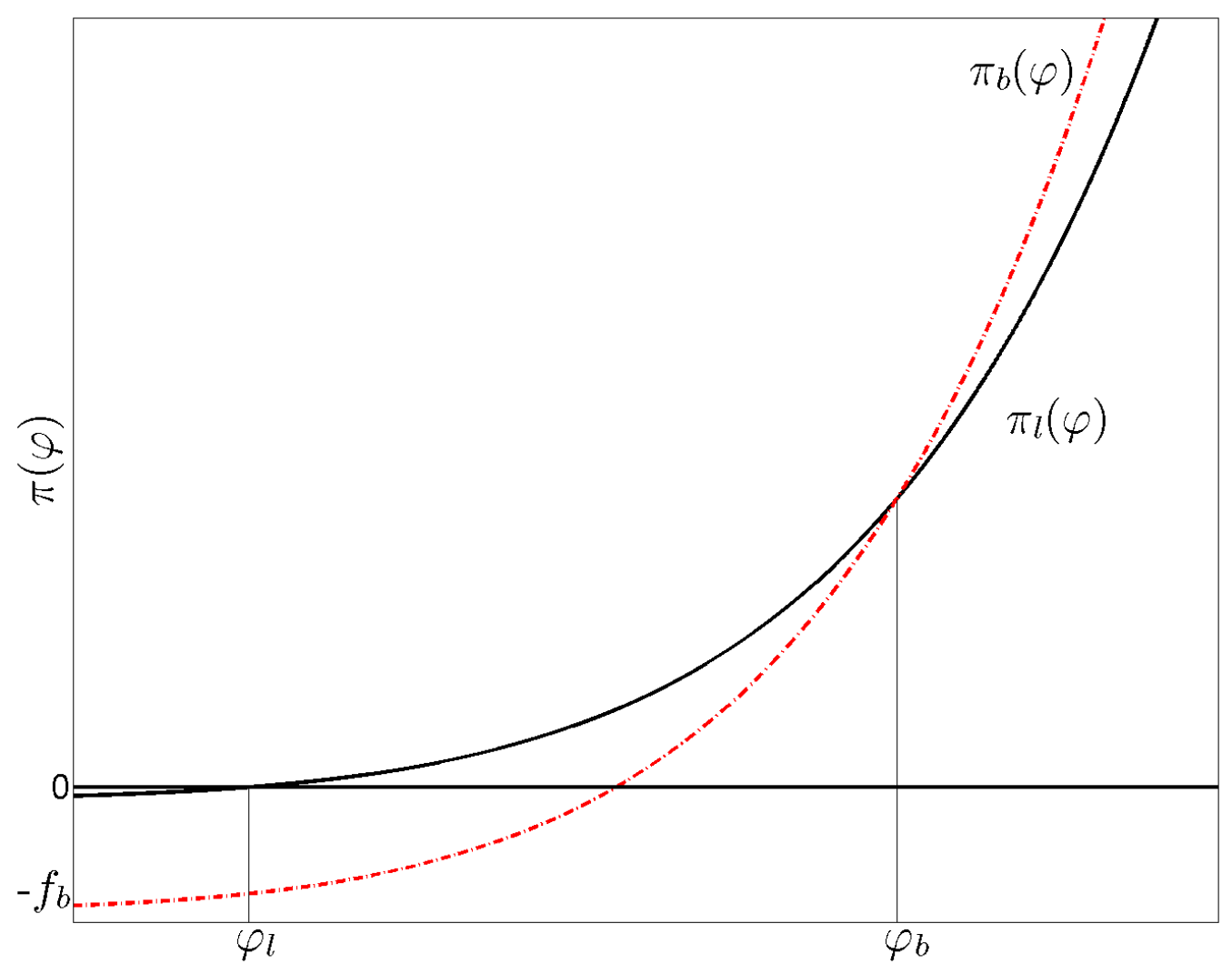

Figure 1: Profit functions and productivity thresholds differ for bank borrowers and bond issuers

Banks must pay an interest rate on deposits used to make loans. In a world with perfectly integrated financial markets, this deposit rate equals the rate of return that investors could earn in the bond market. That is, underwriters ${ }^{11}$ must price the bonds such that the effective yield for bond investors equals the interest rate paid on bank deposits. In equilibrium, both the yield for bond investors and the interest rate on deposits equal the equilibrium market interest rate derived from the consumer's first-order condition, equation (2.6), which in steady-state is given by

$$
r=\frac{1-\beta+\gamma}{\beta}
$$

Suppose that $n_{j} \leq n$ firms use intermediation of type $j(j \in l, b)$ to finance their capital investments. We assume that intermediaries are perfectly competitive, so the expected cost of raising funds and

\footnotetext{
${ }^{11}$ Note that underwriters are the intermediaries in the bond market.
} 
monitoring nonperforming assets must equal the expected gains from extending credit to successful firms who repay all debts with no monitoring,

$$
\delta n_{j} \mu_{j}\left[K_{j}\left(\bar{\varphi}_{j}\right)+f_{j}\right]=(1-\delta) n_{j}\left(r_{j}-r\right)\left[K_{j}\left(\bar{\varphi}_{j}\right)+f_{j}\right]
$$

where $K_{j}\left(\bar{\varphi}_{j}\right)$ is the average size of loans or bonds issued by intermediaries of type $j, \mu_{j}$ is the monitoring cost $\left(0<\mu_{j}<1\right), \gamma$ is the rate of depreciation on capital purchased with the loan, $(1-\gamma)$ is the portion of capital expenditures recoverable by the bank during liquidation, and $r_{l}-r$ is the net return on earned interest revenues after paying interest on bank deposits. ${ }^{12}$ Then we have the interest rate paid on financed capital as a function of the market interest rate earned on deposits or bond holdings, $r$,

$$
r_{j}=\frac{r}{1-\delta}+\frac{\delta \mu_{j}}{1-\delta}
$$

In accordance with empirical findings by Hale and Santos $(2008)$, we suppose that the large fixed cost a firm pays to conduct a viable bond issue makes its operations more transparent to investors - in other words, bond investors incur a smaller monitoring cost than banks to liquidate remaining assets of the firm (and recover their investment) upon exit. Without loss of generality, we assume that the monitoring cost for bond investors equals zero $\left(\mu_{l}=\mu, \mu_{b} \equiv 0\right.$, with $\left.0<\mu<1\right)$, though it need only be less than the monitoring cost for bank lenders for our results to hold. Note that this implies an interest rate for bank loans, $r_{l}=\frac{r}{1-\delta}+\frac{\delta \mu}{1-\delta}$ and that underwriters purchase bonds from bond issuers at a price that results in a marginal cost of capital for firms equal to $r_{b}=\frac{r}{1-\delta}$.

Given the wedge, $\frac{\delta \mu}{1-\delta}$, between the bank interest rate and the yield that firms must pay on bond issues, we have $r_{l}>r_{b}$. This makes the marginal costs of capital lower for bond issuers than for bank borrowers, implying that the profit for bond issuers increases faster in their efficiency level than that of bank borrowers: the right-hand side of equation 2.10 is greater than one.

Figure 1 illustrates how the wedge between the interest rates causes the less productive firms to be bank borrowers and the most productive to be bond issuers. Since the rate of return paid to bondholders and bank depositors is equal, the proportion of savings devoted to bond purchases

\footnotetext{
${ }^{12}$ This condition also holds on a loan-by-loan basis, so it makes no difference whether we formulate it for all loans, $n_{j}\left[K_{j}(\bar{\varphi})+f_{j}\right]$, or for each loan, $K_{j}(\varphi)+f_{j}$.
} 
versus bank deposits is determined entirely by the amount of bonds issued and bank loans demanded by firms.

\subsection{Aggregation}

We assume that each firm draws its idiosyncratic productivity parameter from the cumulative distribution $H(\varphi)$. Denote the mass of firms using bank loans and bond issues to finance capital investment as $n_{l}$ and $n_{b}$, respectively. Let $n$ equal the total number of entrants in the intermediate goods sector (including firms who must immediately exit upon observing that they have a productivity level less than $\left.\varphi_{l}\right)$. Then, $n_{l}=\operatorname{Prob}(\operatorname{loan}) \times n=\left[H\left(\varphi_{b}\right)-H\left(\varphi_{l}\right)\right] n$ and $n_{b}=\operatorname{Prob}($ bond $) \times n=\left[1-H\left(\varphi_{b}\right)\right] n$.

The segmentation between bank and bond financers allows us to reduce the aggregate price level, equation (2.7), to a function of the wage and the bond yield,

$$
\begin{aligned}
P= & \left(\frac{1}{H\left(\varphi_{b}\right)-H\left(\varphi_{l}\right)} \int_{0}^{n_{l}} \int_{\varphi_{l}}^{\varphi_{b}} p_{l}(\varphi)^{1-\sigma} d H(\varphi) d i+\frac{1}{1-H\left(\varphi_{l}\right)} \int_{n_{l}}^{n_{l}+n_{b}} \int_{\varphi_{b}}^{\infty} p(\varphi)^{1-\sigma} d H(\varphi) d i\right)^{\frac{1}{1-\sigma}} \\
= & \frac{\sigma}{\sigma-1} \frac{w^{\alpha}}{(1-\alpha)^{1-\alpha} \alpha^{\alpha}} \\
& \times\left(\frac{n_{l}}{H\left(\varphi_{b}\right)-H\left(\varphi_{l}\right)} \int_{\varphi_{l}}^{\varphi_{b}}\left(r_{l}^{\alpha-1} \varphi\right)^{\sigma-1} d H(\varphi)+\frac{n_{b}}{1-H\left(\varphi_{l}\right)} \int_{\varphi_{b}}^{\infty}\left(r_{b}^{\alpha-1} \varphi\right)^{\sigma-1} d H(\varphi)\right)^{\frac{1}{1-\sigma}} \\
= & \frac{\sigma}{\sigma-1} \frac{w^{\alpha}}{(1-\alpha)^{1-\alpha} \alpha^{\alpha} \bar{\varphi}},
\end{aligned}
$$

where

$$
\bar{\varphi}=\left(n_{l} r_{l}^{-(1-\alpha)(\sigma-1)} \bar{\varphi}_{l}^{\sigma-1}+n_{b} r_{b}^{-(1-\alpha)(\sigma-1)} \bar{\varphi}_{b}^{\sigma-1}\right)^{\frac{1}{\sigma-1}}
$$

is the average efficiency level - the harmonic mean of all firm efficiency parameters weighted by the influence of their respective interest payments on their price-setting behavior. Here, the average efficiency levels among bank borrowers and bond issuers are, respectively, $\bar{\varphi}_{l}^{\sigma-1} \equiv \frac{1}{H\left(\varphi_{b}\right)-H\left(\varphi_{l}\right)} \int_{\varphi_{l}}^{\varphi_{b}} \varphi^{\sigma-1} d H(\varphi)$ and $\bar{\varphi}_{b}^{\sigma-1} \equiv \frac{1}{1-H\left(\varphi_{b}\right)} \int_{\varphi_{b}}^{\infty} \varphi^{\sigma-1} d H(\varphi)$. 


\subsection{Defining the size of the financial sectors}

If, we make the simple standard assumption that efficiency draws are Pareto distributed, so that $H(\varphi)=1-\varphi^{-\theta}$, then $\bar{\varphi}$ in equation 2.16 reduces to

$$
\bar{\varphi}=\left[\left(\frac{\theta n}{\theta-(\sigma-1)}\right)\left(r_{l}^{-(1-\alpha)(\sigma-1)}\left(\varphi_{l}^{(\sigma-1)-\theta}-\varphi_{b}^{(\sigma-1)-\theta}\right)+r_{b}^{-(1-\alpha)(\sigma-1)} \varphi_{b}^{(\sigma-1)-\theta}\right)\right]^{\frac{1}{\sigma-1}}
$$

Using the reduced definition of $P$ above (2.15), it is straightforward to derive the relationship between $\varphi_{b}$ and $\varphi_{l}$. First, we use the zero profit condition for bank borrowers, which reduces to

$$
\varphi_{l}=\left(\frac{\sigma\left(1+r_{l}\right) f_{l}}{Y}\right)^{\frac{1}{\sigma-1}} r_{l}^{1-\alpha} \bar{\varphi}
$$

Above, we showed that under reasonable assumptions, the least productive firms in the economy are bank borrowers. The zero profit equation tells us that anything which increases firm profitability for bank borrowers - a bigger market $(Y)$, a greater love of variety (lower $\sigma$ ), a lower interest rate $\left(r_{l}\right)$, or a lower fixed cost for loans $\left(f_{l}\right)$-reduces the productivity threshold for bank borrowers, allowing extra firms at the margin to operate in the economy.

Then, we use the fact that the marginal bond market participant is indifferent between financing capital expenditures using bank loans or public debt, manifest in equation 2.11. Substituting the expressions for the aggregate price level and threshold bank borrower (equations (2.15) and 2.17), this simplifies to

$$
\begin{aligned}
\varphi_{b}^{\sigma-1} & =\left[\frac{\left[\left(1+r_{b}\right) f_{b}-\left(1+r_{l}\right) f_{l}\right]}{\left(r_{b}^{(1-\alpha)(1-\sigma)}-r_{l}^{(1-\alpha)(1-\sigma)}\right)} \cdot \frac{\sigma}{Y}\right] \bar{\varphi}^{\sigma-1} \\
\varphi_{b}^{\sigma-1} & =\frac{\left(1+r_{b}\right) f_{b}-\left(1+r_{l}\right) f_{l}}{\left(1+r_{l}\right) f_{l}} \cdot \frac{r_{l}^{(1-\alpha)(1-\sigma)}}{r_{b}^{(1-\alpha)(1-\sigma)}-r_{l}^{(1-\alpha)(1-\sigma)}} \varphi_{l}^{\sigma-1} \\
\varphi_{b} & =\chi \varphi_{l},
\end{aligned}
$$

where $\chi=\left[\frac{\left(1+r_{b}\right) f_{b}-\left(1+r_{l}\right) f_{l}}{\left(1+r_{l}\right) f_{l}} \cdot \frac{r_{l}^{(1-\alpha)(1-\sigma)}}{r_{b}^{(1-\alpha)(1-\sigma)}-r_{l}^{(1-\alpha)(1-\sigma)}}\right]^{\frac{1}{\sigma-1}}$. We assume that the fixed cost of bonds is sufficiently large that $\chi$ is always greater than one, implying that bond issuers are always more efficient than the most efficient bank borrower, given in equation 2.12 . 


\subsection{Aggregate factor input demand}

We now turn to obtaining expressions for aggregate labor demand and supply, capital demand and supply, and the wage rate. We assume that exitors can not hire labor. It is straightforward to show that $L_{j}^{d}=(1-\delta) n_{j} L\left(\bar{\varphi}_{j}\right)$, meaning that total labor demanded by successful firms using bank loans, for instance equals the labor demanded by the average firm using bank loans, times the number of firms using bank loans. The aggregation of the capital stock and firm profits for intermediate goods producers also yields $K_{j}^{d}=n_{j} K_{j}\left(\bar{\varphi}_{j}\right)$ and $\Pi_{j}=(1-\delta) n_{j} \pi_{j}\left(\bar{\varphi}_{j}\right)$.

Now turn to the aggregate demand for labor. First, recall that labor demand by a firm with efficiency parameter $\varphi$ is given by

$$
L_{j}^{d}(\varphi)=\frac{1}{\varphi}\left[\left(\frac{1-\alpha}{\alpha}\right) \frac{w}{r_{j}}\right]^{\alpha-1} y(\varphi)
$$

Substituting the demand function for intermediate goods 2.8 yields

$$
L_{j}^{d}(\varphi)=\left(\frac{1-\alpha}{\alpha}\right)^{\alpha-1} \frac{w^{\alpha-1}}{A} r_{l}^{-(1-\alpha)(\sigma-1)} \bar{\varphi}^{-\sigma} \varphi^{\sigma-1} Y
$$

Total labor demand is equal to the sum of labor demand for bank borrowers and bond issuers:

$$
\begin{aligned}
L^{D} & =L_{b}^{d}+L_{l}^{d} \\
& =(1-\delta)\left[n_{l} L\left(\bar{\varphi}_{l}\right)+n_{b} L\left(\bar{\varphi}_{b}\right)\right] \\
& =(1-\delta)\left(\frac{1-\alpha}{\alpha}\right)^{\alpha-1} \frac{w^{\alpha-1}}{A \bar{\varphi}^{\sigma}} Y\left(n_{l} r_{l}^{-(1-\alpha)(\sigma-1)} \bar{\varphi}_{l}^{\sigma-1}+n_{b} r_{b}^{-(1-\alpha)(\sigma-1)} \bar{\varphi}_{b}^{\sigma-1} d H(\varphi)\right) \\
& =(1-\delta)\left(\frac{1-\alpha}{\alpha}\right)^{\alpha-1} \frac{w^{\alpha-1}}{\bar{\varphi}} Y \\
& =\alpha(1-\delta)\left(\frac{\sigma-1}{\sigma}\right) \frac{P Y}{w},
\end{aligned}
$$

an inverse function of the real wage.

Setting labor supply equal 2.3 to labor demand 2.8,

$$
\left(\frac{w}{P}\right)^{\frac{1}{\psi-1}}=\alpha(1-\delta)\left(\frac{\sigma-1}{\sigma}\right) \frac{P Y}{w}
$$

yields an expression for the wage in terms of parameters, final goods output, and the aggregate 
productivity level,

$$
w=\left(\frac{\sigma}{\sigma-1}\right)^{\frac{1}{(1-\alpha) \psi}}(1-\alpha)^{-1} \alpha^{\frac{\psi-\alpha \psi-1}{\psi(1-\alpha)}}\left(\frac{1}{A \bar{\varphi}}\right)^{\frac{1}{1-\alpha}}[(1-\delta) Y]^{\frac{\psi-1}{(1-\alpha) \psi}}
$$

The aggregate demand for capital is the sum of each firm's demand for capital, which is decreasing in the output-weighted loan and bond interest rates,

$$
\begin{aligned}
K^{D} & =K_{l}^{d}+K_{b}^{d} \\
& =n_{l} K\left(\bar{\varphi}_{l}\right)+n_{b} K\left(\bar{\varphi}_{b}\right) .
\end{aligned}
$$

The capital borrowed by exitors does not disappear upon exit, so we do not subtract it from the total demand for capital as we did for total labor demand.

\subsection{Free entry and aggregate stability}

Every entrepreneur who decides to enter the market pays an entry fee, $f_{e}$, denominated in units of the final good, for the right to draw a productivity parameter, $\varphi$. Some of these firms draw $\varphi<\varphi_{l}$

and exit immediately. In equilibrium, the expected value of entry, given the uncertainty that an entrant will be successful, must equal the entry fee. In steady-state the condition is

$$
\bar{v}=\frac{\bar{\pi}}{\delta(1-\beta)} \equiv P_{t} f_{e}
$$

where $\bar{\pi}$ denotes average profits, or

$$
\begin{aligned}
\bar{\pi} & =\left(\frac{n_{l}}{n}\right) \pi_{l}\left(\bar{\varphi}_{l}\right)+\left(\frac{n_{b}}{n}\right) \pi_{b}\left(\bar{\varphi}_{b}\right) \\
& =\left[H\left(\varphi_{b}\right)-H\left(\varphi_{l}\right)\right] \pi_{l}\left(\bar{\varphi}_{l}\right)+\left[1-H\left(\varphi_{b}\right)\right] \pi_{b}\left(\bar{\varphi}_{b}\right) .
\end{aligned}
$$

In addition, given the uniform probability that a firm will experience forced exit in any period, equilibrium requires the number of new entrants in each period that are sufficiently productive to survive equal the number of forced exitors. That is,

$$
\left[1-H\left(\varphi_{l}\right)\right] n_{e}=\delta n .
$$


This aggregate stability condition implies that total fees paid by businesses to find out their individual efficiency level, $\varphi$, equals

$$
n_{e} P f_{e}=\frac{\delta n}{\left[1-H\left(\varphi_{l}\right)\right]} P f_{e}
$$

\subsection{Solving for the closed-economy steady state equilibrium}

To solve for the steady state equilibrium for the closed economy, we begin with the steady-state version of the goods market clearing condition,

$$
P Y=P C+P I=P C+\gamma P K
$$

Then the consumer's budget constraint, equation $(2.2)$, becomes

$$
P Y=w L+\left(1+r_{b}-\gamma\right) P K+\Pi^{F}+\Pi^{I}
$$

To compute aggregate firm profits, we note once more that total profits earned by firms that use financing method $j$ equals $n_{j} \pi_{j}\left(\bar{\varphi}_{j}\right)$. integrate profit for each individual firm,

$$
\begin{aligned}
\Pi^{F} & =(1-\delta)\left[n_{l} \pi_{l}\left(\bar{\varphi}_{l}\right)+n_{b} \pi_{b}\left(\bar{\varphi}_{b}\right)\right] \\
& =\frac{(1-\delta) P^{\sigma} Y}{\sigma}\left(n_{l} p_{l}\left(\bar{\varphi}_{l}\right)^{1-\sigma}+n_{b} p_{b}\left(\bar{\varphi}_{b}\right)^{1-\sigma}\right)-P\left[n_{l}\left(1+r_{l}\right) f_{l}+n_{b}\left(1+r_{b}\right) f_{b}\right] \\
& =\frac{P Y}{\sigma}-P\left(n_{l}\left(1+r_{l}\right) f_{l}+n_{b}\left(1+r_{b}\right) f_{b}\right) .
\end{aligned}
$$

We assume that fixed costs are fees that intermediaries transmit directly back to consumers as dividends without any impact on the labor market, ${ }^{13}$

$$
\Pi^{I}=P\left[(1-\delta) n_{l}\left(1+r_{l}\right) f_{l}+(1-\delta) n_{b}\left(1+r_{b}\right) f_{b}+n_{e} f_{e}\right]
$$

The total value of expenditures, $P Y$, is equal to the number of firms times average firm revenues,

\footnotetext{
${ }^{13}$ In reality, there is a market for this type of financial service and the amount of labor skilled in providing such services can be an important factor in the financial development and growth of an economy. We leave this question for future research.
} 
$\bar{\rho}: P Y=n \bar{\rho}$. Then, noting that $\pi_{j}(\varphi)=\frac{r_{j}(\varphi)}{\sigma}-P\left(1+r_{j}\right) f_{j}$, we have

$$
\begin{aligned}
n & =\frac{P Y}{\bar{\rho}} \\
& =\frac{P Y}{\sigma\left(\bar{\pi}+(1-\delta) \frac{n_{l}}{n}\left(1+r_{l}\right) P f_{l}+(1-\delta) \frac{n_{b}}{n}\left(1+r_{b}\right) P f_{b}\right)} .
\end{aligned}
$$

The steady state free entry condition yields a simple expression for $\bar{\pi}$,

$$
\begin{aligned}
\left(\frac{1}{(1-\beta) \delta}\right) \bar{\pi} & \equiv P f_{e} \\
\bar{\pi} & =(1-\beta) \delta P f_{e} .
\end{aligned}
$$

Substituting into our expression for $n$ yields

$$
\begin{aligned}
n & =\frac{P Y}{\sigma\left((1-\beta) \delta P f_{e}+(1-\delta) \frac{n_{l}}{n} P f_{l}+(1-\delta) \frac{n_{b}}{n} P f_{b}\right)} \\
& =\frac{Y}{\sigma\left((1-\beta) \delta f_{e}+\left[H\left(\varphi_{b, t}\right)-(1-\delta) H\left(\varphi_{l, t}\right)\right] f_{l}+(1-\delta)\left[1-H\left(\varphi_{b, t}\right)\right] f_{b}\right)} .
\end{aligned}
$$

We combine equation (2.21) with equations 2.13, 2.14, 2.15, 2.8, 2.19, 2.20, 2.18, $2.22,2.23$, and 2.24 to find the equilibrium quantities $\left\{P, Y, L, K_{l}, K_{b}, w, r_{b}, r_{l}, \varphi_{b}, \varphi_{l}, n\right\}$. Solving the model, we can study the impact of changes in transactions costs and the bank monitoring costs on sectoral reallocation, output, and welfare.

\section{Calibration}

Exact figures for the size of the bond issuance costs $f_{b}$ that are comparable across countries are difficult to find. Table 1 shows available estimates for 10 different countries. For Bangladesh, India, Nepal, and Pakistan, the fees are dramatically understated in comparison to Brazil, Mexico, and Chile because they omit the ratings fees and underwriting fees by investment banks, which are included in the estimates for the Latin American countries and together constitute the lion's share

of the cost of issuance (up to $95 \%$ in Brazil, for instance, according to Zervos (2004)). Commissions and fees for bond issues, are conservatively estimated at $7.4 \%$ of the size of total issues for Pakistan (Sophastienphong, Mu, and Saporito, 2008), compared to 0.7-1.3\% in the United States Ong and Luengnaruemitchai, 2005). The fixed costs involved in bank lending $f_{l}$ are considerably smaller 
than those involved in the issuance of securities: non-interest income for the average U.S. bank is $1 \%$ of bank assets, with just over half of that earned as fees related to deposit transactions, rather than lending (DeYoung and Rice, 2006). Thus, even in the U.S., the cost of initiating a bond issue is likely to be about twice the size of the fixed transactions costs involved in arranging the typical commercial bank loan. In our experiments we consider two alternative values for the bond issuance costs $f_{b}$. As an upper bond, we set $f_{b}$ equal to 10 times the cost of obtaining a bank loan $f_{l}\left(f_{b}=5, f_{l}=0.5\right)$, corresponding to the ratio of Pakistan's reported issuance cost to US bank lending fees. As a lower bound, we set $f_{b}$ equal to twice the costs of obtaining a bank loan $\left(f_{b}=1, f_{l}=0.5\right)$, approximating the ratio observed in the United States.

Table 2 shows evidence regarding the size of the other two financial friction parameters, the fraction of default of bank monitored loans $(\delta)$ and the cost of monitoring those loans $(\mu)$. Estimates of the default rate $\delta$ for non-syndicated loans vary widely, from less than 1 percent in South Korea to 6 percent in Portugal, to almost 12 percent for small businesses in the United States in 2008. We choose a middle ground of 5 percent, $\delta=0.05$. The monitoring cost $\mu$ corresponds with the sum of the administrative costs of recovery for defaulted assets and the fraction of the loan that can not be recovered - termed loss given default within the Basel Standards. Estimates of direct administrative costs incurred to recover of assets in U.S. bankruptcy courts are up to $10 \%$ of the value of bankruptcy estates (Fisher and Martel, 2008). Estimates of loss given default again vary widely by country and the type of firm, as well as the nature of a firm's relationship with the bank that loans it money, and macroeconomic conditions. We choose a range of values for $\mu$ in our policy experiments. As an upper bond, we set the monitoring cost to be equal to $40 \%$ in the range observed in Latin America (Dermine and de Carvalho, 2006). For the lower bound, we set the monitoring costs to 10\%, a figure between the lowest level observed in Portugal (8 percent) and in the U.S. (13 percent).

We choose standard values for the remaining parameters. We set the elasticity of substitution $\sigma$ equal to 8, based on the range of estimates found in Feenstra (1994) and Broda and Weinstein (2006), with the Pareto shape parameter, $\theta$, set equal to $\sigma$ in order to capture the degree of dispersion in firm size seen in Helpman, Melitz, and Yeaple (2004). The cost share of labor in the production function $(\alpha)$ is 0.65 and we set the elasticity of the labor supply $\psi$ equal to 2 . The results are robust to a range of values for these parameters. 


\section{Results}

\subsection{Intra-industry reallocation of output}

Table 3 shows the calibration of the key policy parameters: the bond issuance costs, the bank loan access cost, and bank monitoring costs. The table also shows the resulting solutions for the endogenous variables as we vary the level of the bond issuance cost parameter, $f_{b}$, and the level of the bank monitoring cost parameter, $\mu$. Going from columns (2) to (1) and (4) to (3), the table shows changes in the endogenous variables as the fixed cost of bond issuance falls from 10 times the size of the fixed cost involved in securing bank credit (as for Pakistan, for instance) to a level twice the size of the fixed cost of bank credit (as for the United States). Comparing column (2) to column (1), the table shows the effects of lowering the bond issuance cost parameter $f_{b}$ for a low level of monitoring cost $(\mu=0.1)$. Comparing column (4) to column (3), the table shows the effects of lowering bond issuance costs when monitoring costs are "high," with $\mu=0.4$.

Figures $2 \mathrm{a}$ and $2 \mathrm{~b}$ show the level of output produced and profit earned by firms with different levels of idiosyncratic efficiency, $\varphi$. Figure 2a reveals the intra-industry reallocation of production induced by falling bond issuance costs. Mid-size firms, the ones switching from bank loans to bond issues, expand and the largest and smallest firms - the non-switchers - contract a bit. The switchers experience a drop in their marginal cost of capital financing, which they pass on to the consumer in the form of lower prices, boosting the demand for their products. The non-switchers lose market share to the switchers and must pay higher labor costs, as the expansion of the switchers drives up the real wage. The scale effect for switchers is therefore a first-order effect of reducing $f_{b}$, while the scale effect for non-switchers is smaller, a second-order effect.

The intra-industry reallocation also involves a reduction on the extensive margin. Regardless of the size of monitoring costs, as the bond issuance cost, $f_{b}$, falls from 5 to 1 the threshold efficiency level for active production, $\varphi_{l}$, rises. This means that the number of active firms fall as access to bond markets gets easier. The smallest firms are pushed out, unable to turn a profit amidst higher labor costs and market shares squeezed by the expanding switchers. At the same time, the threshold efficiency level for bond issuers, $\varphi_{b}$, falls. Thus, the number of bank borrowers falls due to exit on the low end of the productivity spectrum and due to switching into bond issuance. Though non-switchers shrink in size, the increase in aggregate output $Y$ seen in Table 3, combined with the 
lower number of active firms, implies a net increase in the intensive margin for the average firm. The contraction at the extensive margin also results in an increase in average productivity, $\bar{\varphi}$. It is plain to see that the sectoral reallocation is driven primarily by switching, rather than exit, as the threshold efficiency level for bond issuance, $\varphi_{b}$, drops much more precipitously than the efficiency level for the marginal bank borrower, $\varphi_{l}$, rises. In sum, we see production reallocated away from the smallest and the largest firms, toward the mid-size switchers, whose aggregate expansion exceeds the aggregated contraction of the non-switchers. ${ }^{14}$

To further understand the reasons behind the intra-industry reallocation following a drop in the bond issuance costs, it is useful to consider the profit functions of the bond issuers and the bank borrowers seen in Figure 2b. A drop in bond issuance costs, by itself, immediately raises the profits for all bond borrowers as their fixed costs are lower. This entices firms on the margin that were not issuing bonds to start issuing ( $\varphi_{b}$ falls). As mentioned above, those firms experience a large reduction in their marginal cost of capital, allowing them to drop prices for their products, and to increase their output. The increase in the real wage drives up marginal costs for all firms, particularly for those firms that do not switch their source of financing, lowering their profits. Thus, the smallest and the largest firms that did not switch pass the increased labor costs on to consumers in the form of higher prices, ultimately reducing their output and dampening profits despite the increase in aggregate consumption. We observe profits reallocated away from the non-switchers at either end of the efficiency spectrum toward the switchers in the middle.

Sectoral reallocation from a drop in bond issuance costs is most pronounced when the banking sector is less efficient ( $\mu$ is "high"). As Figure 3 and Table 3 show, when monitoring costs are high there is much greater growth of the bond market relative to bank loans, measured either as the ratio of bond issuers to bank borrowers or as the total amount of bond issues relative to bank credit. In Table 3, when bond issuance costs drop and bank monitoring costs are low (going from columns (2) to (1)) the number of bank borrowers drops by 6 percent. When bank monitoring costs are high (going from columns (4) to (3)) the number of bank borrowers drops by 33 percent-more than five times as much turnover. Turnover among bank borrowers boosts average firm productivity when the least efficient firms exit and reduces prices through switching, generating larger increases

\footnotetext{
${ }^{14}$ The reallocation of production toward the middle of the efficiency spectrum also reduces reduces dispersion in the distribution of firm size.
} 


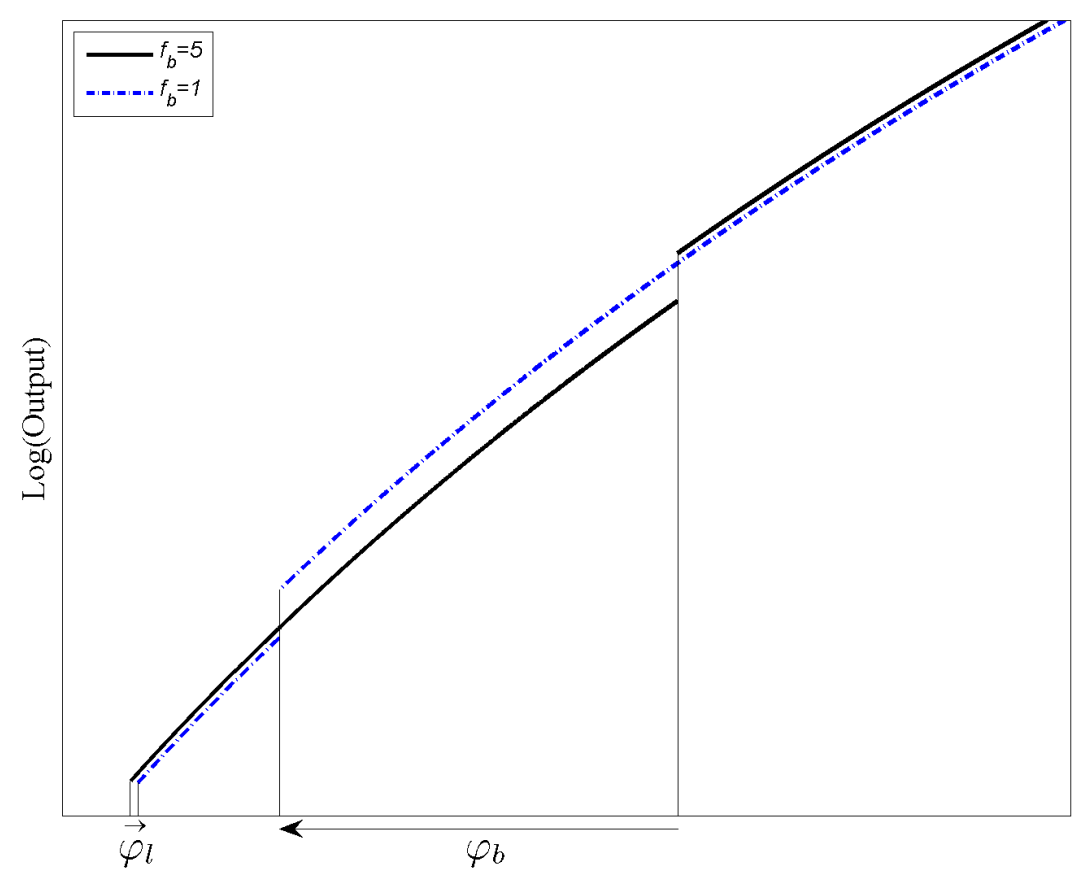

(a) Output



(b) Profit

Figure 2: Reallocation of output across firm efficiency levels when $f_{b}$ falls 
in aggregate consumption, output, and welfare compared to when monitoring costs are low. The augmented impacts seen when the monitoring cost $\mu$ is high are related to the exit factor, rather than switching. Roughly the same amount of switching, measured by the percent change in $\varphi_{b}$ and $n_{b}$, occurs whether the monitoring costs are high or low, but the switching pushes up the real wage more when monitoring costs are high because the switch from bank to bond financing provides an even bigger discount on marginal cost of capital and thus on the price of goods produced by switchers. Thus, the real wage, which increases almost 5 times more as $f_{b}$ falls when monitoring costs are high, drives the extra exit among the smallest bank borrowers.

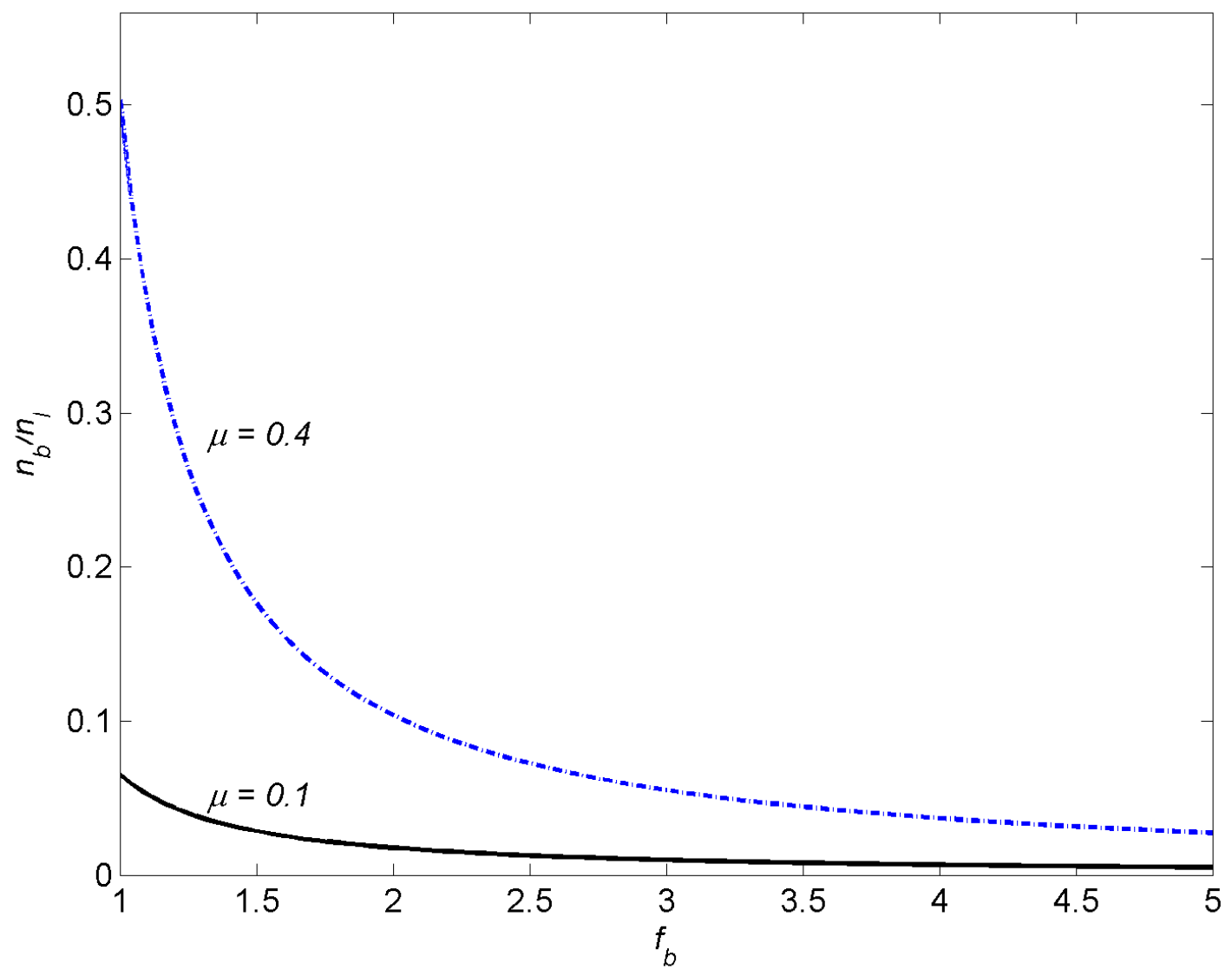

Figure 3: The number of bond issuers relative to bank borrowers increases faster as issuance costs fall when bank monitoring costs are high

A reduction in bank monitoring costs has qualitatively different impacts on sectoral reallocation than a reduction in bond issuance costs. In Table 3 , we show results from a drop in bank monitoring 
costs $\mu$ when bond issuance costs $f_{b}$ are "low" (going from columns (3) to (1)) and when bond issuance costs are "high" (going from columns (4) to (2)). Reducing bank monitoring costs reduces the marginal costs of all bank borrowers, affecting both the intensive and extensive margins. Along the extensive margin, a reduction in borrowing costs for bank borrowers raises their profitability. Thus, low-productivity firms that previously lay dormant begin to produce ( $\varphi_{l}$ falls). Moreover, some bond issuers now find it optimal to switch to bank borrowing ( $\varphi_{b}$ rises). Those firms that switch from issuing bonds to borrowing from banks enjoy lower fixed costs, but experience an increase in marginal costs, which compels them to increase their prices and face lower demand for their output. All firms that already were borrowing from banks experience a drop in marginal costs directly as a result of the drop in bank monitoring costs and they increase their output.

Aggregate output, labor demand and real wages seen in Table 3 increase when $\mu$ falls. As in the case of lowering bond issuance costs, the second-order effect on the real wage increases the marginal costs of bond issuers that do not switch into bank borrowing. The incumbent bond issuers also find their market share redirected toward incumbent bank borrowers who pass lower financing costs on to consumers as lower goods prices. Thus, a reduction in bank monitoring costs causes entry into production. It reallocates production away from mid-sized firms (and to a lesser extent, away from the largest firms) toward the smallest firms, including new entrants. At the same time, it reallocates profits away from the largest firms toward both mid-size and small firms. The mid-size firms that benefit here - in contrast to the case of reduced costs of bond issuance - are not just firms that switch their source of financing in order to take advantage of the falling bank interest rates. They include the smallest switchers, for whom the reduced fixed costs from switching into bank loans outweigh the increased marginal costs of bank financing and higher real wages, as well as the largest incumbent bank borrowers, for whom reduced financing costs outweigh higher real wages. The impact on the real wage, aggregate output, and welfare is bigger when the fixed cost of bond issuance is high because there are more and larger incumbent bank borrowers benefitting from the lower bank financing costs and responding by lowering their prices.

There is a suggestion in the literature on financial development (see the brief survey in Beck, Demirgüç-Kunt, Laeven, and Levine (2008)) that since mainly large firms issue public debt and because debt issuance involves large fixed transactions costs, bond market development probably favors large large firms over smaller firms. Figure 2 shows that in the stylized setting of our model, 


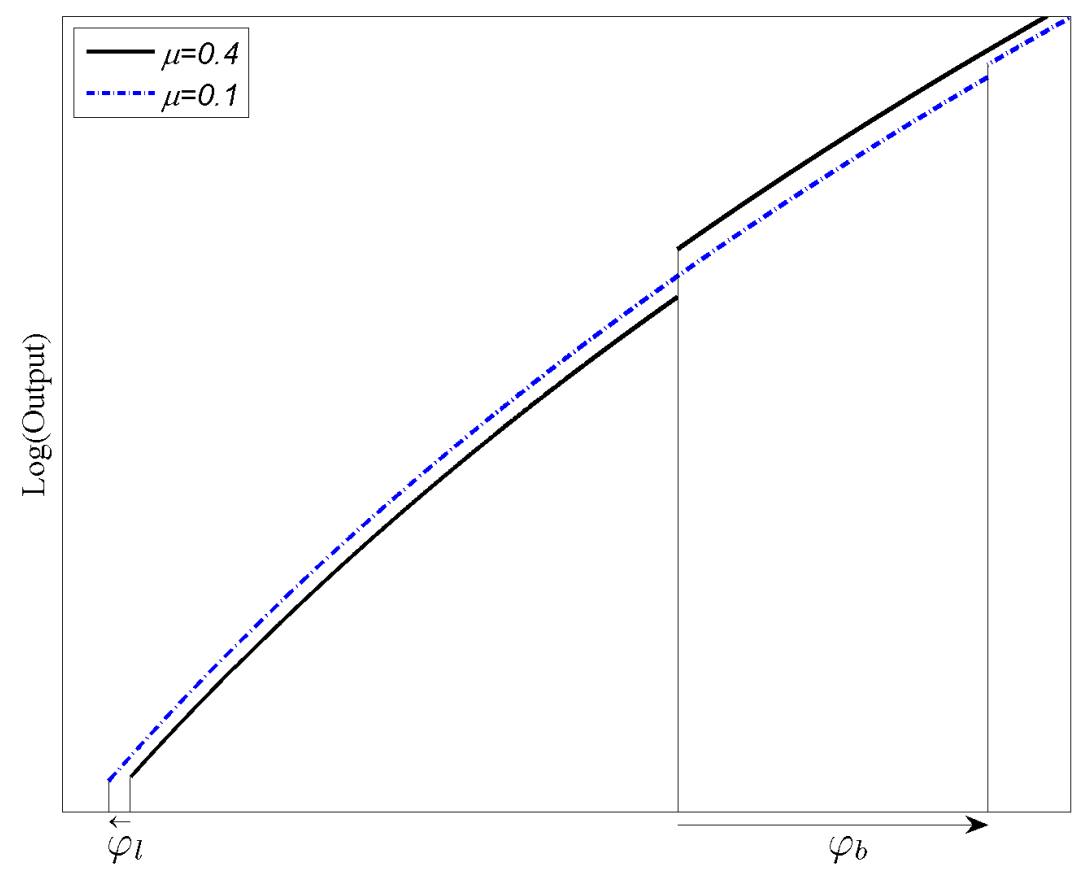

(a) Output

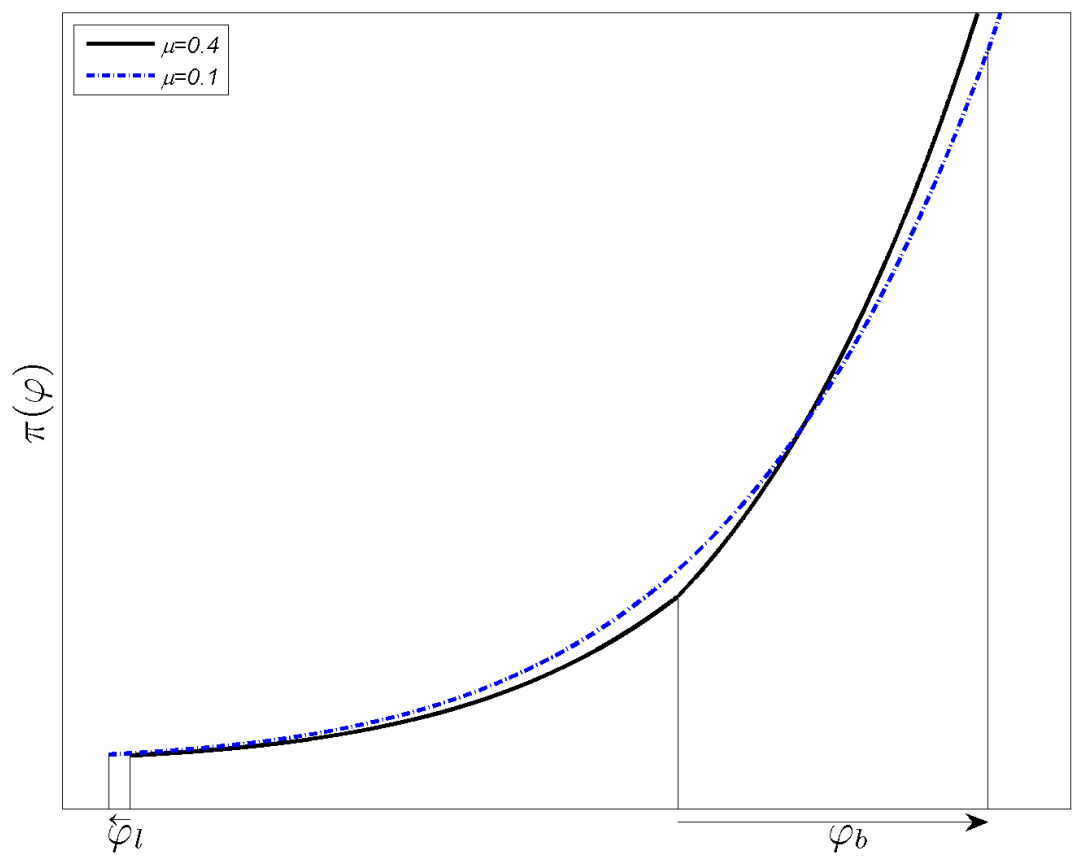

(b) Profit

Figure 4: Reallocation of output across firm efficiency levels when bank monitoring cost $\mu$ falls 
the effects are somewhat nuanced. On the one hand, small firms are pushed out, as noted above, and the remaining bank borrowers (all at the lower end of the firm size distribution) see a decrease in output. On the other hand, the largest firms, incumbent bond issuers, also see a small reduction in output. What is striking is that it is the medium-sized firms that switch from bank-borrowing to bond issuance that experience a large increase in output. We qualify this as "large" because, as Table 4 shows, the increase in output by these switching firms must overweight the reduction in output from the firms that do not switch and the firms that exit, as the overall output of the economy grows.

\subsection{Financial market development, intra-industry reallocation and welfare}

In our model, reducing the fixed cost of bond issuance results in an increase in welfare, consumption, the real wage, and the capital stock, as does reducing the monitoring cost. As we saw in the previous subsection, a drop in bond issuance costs reduces the number of active firms. However, the shrinking number of firms occurs simultaneously with an increase in the capital stock, employment, the wage (both the nominal and the real wage), the capital-to-labor ratio, and consumption, as the number of firms in the bond-issuing sector increases. The overall capital stock increases, as does the capitalto-labor ratio for the economy as a whole.

Figure $5 \mathrm{a}$ shows the level of welfare and output for different levels of bond issuance costs, $f_{b}$. Lower levels of bond issuance costs are associated with higher bond market development, measured as the stock of total issues. Each line maps the level of welfare attained at various levels of bond issuance costs, given a particular monitoring cost $\mu$. Lower levels of $\mu$ are associated with a higher level of banking sector development, measured by the total stock of bank loans.

Welfare improves as bond issuance costs fall, regardless of the level of the bank monitoring costs. Note that the welfare benefits of lowering the bond issuance cost accelerates as the issuance cost gets smaller. This is because progressively more firms are able to issue bonds for each incremental reduction of $f_{b}$ when the marginal issuer springs from further and further down the spectrum of efficiency levels (Figure 3). ${ }^{15}$ So, it is welfare-improving for a country to develop its bond mar-

\footnotetext{
${ }^{15}$ That is, the hazard rate for the Pareto distribution, $\frac{\theta}{\varphi}$, increases as we move down the hierarchy of efficiency levels. Thus, the size but not the direction of welfare impacts from bond market development is sensitive to the Pareto shape parameter governing the distribution of efficiency levels. The elasticity of substitution has a similar impact, as it influences the distribution of firm size and therefore the rate of switching.
} 


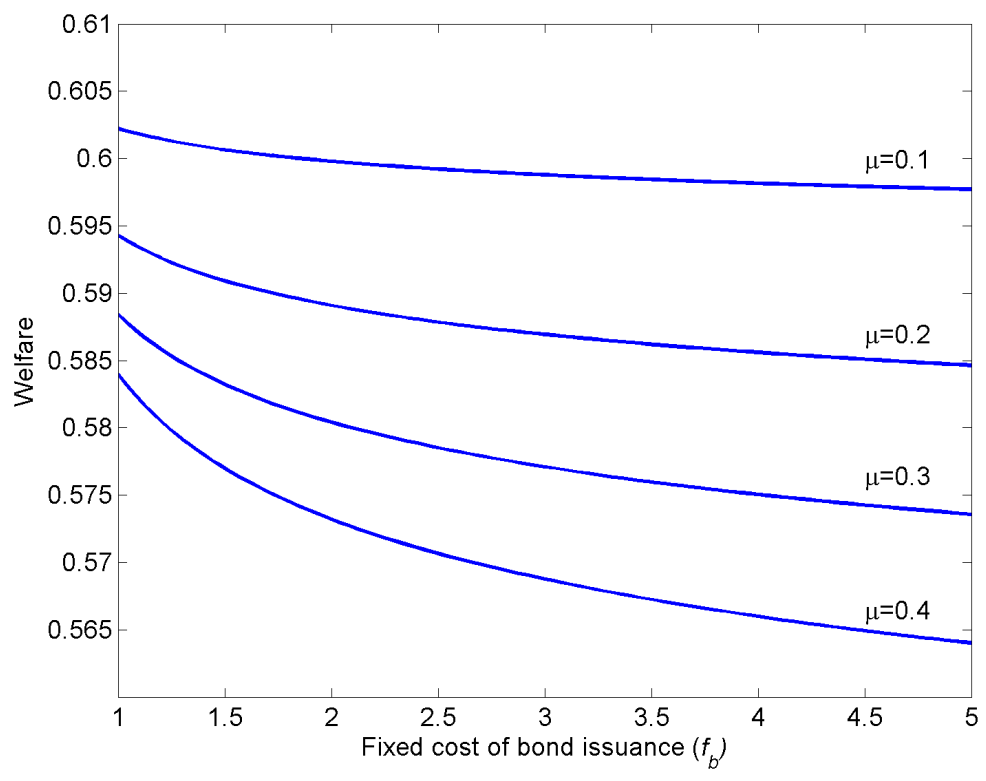

(a) Welfare

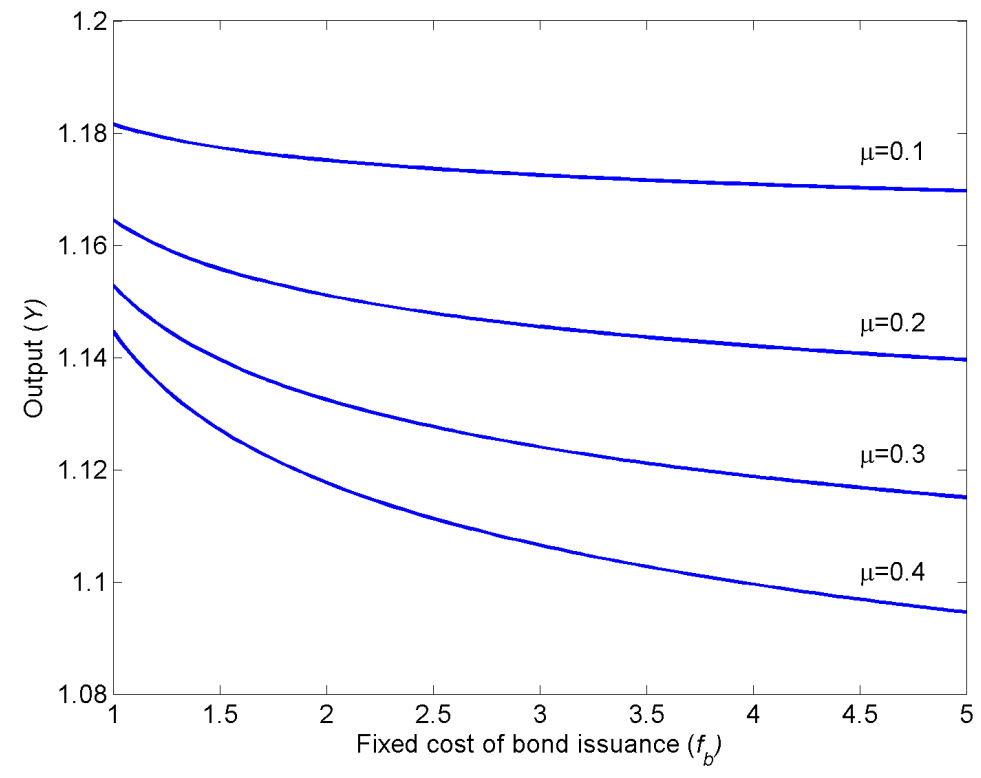

(b) Aggregate Output

Figure 5: Impacts of Bank v. Bond Market Development on Welfare and Output 
ket using policies that reduce issuance costs and there are increasing returns to each incremental reduction.

Regardless of the actual size of the issuance cost, the aggregate effects of lowering bond issuance costs depend on the relative efficiency of the bank sector. The impact of bond market development is much bigger when the banking sector is less efficient-when monitoring costs are large. Higher monitoring costs drive up the cost of financing for bank borrowers so that access to cheaper bond financing packs a bigger punch in lowering the unit cost of production and thus the aggregate price

level. In the model, subsidizing bank credit is observationally equivalent to lowering monitoring costs. A country that subsidizes bank loans naturally will find it harder to increase the relative importance of its bond market by reducing issuance costs. This is evident in Table 3, as the level of bank credit declines less and the ratio of bond issues to bank credit grows less as $f_{b}$ falls when the monitoring cost $\mu$ is low.

\section{Conclusions}

We have drawn on stylized facts from the empirical finance literature regarding firm size and the choice between bank credit and bond issues to build a general equilibrium model that allows us to analyze the macroeconomic effects of financial policies targeted at particular credit markets. The reallocation of production across firms is quite different when increasing the efficiency of the banking sector as opposed to reducing issuance costs to increase access to the bond market. Increasing bank efficiency by reducing monitoring costs reallocates production toward the smallest firms and even allows very small new firms to start producing. The expansion and price cuts among incumbent bank borrowers, as well as additional labor demand among new entrants, drives up the real wage. It also induces some mid-size firms to switch from bond issues to bank borrowing, increasing their marginal costs and thus their prices, contracting demand for their individual goods relative to those of non-switchers. Production by the largest firms that continue issuing bonds drops a bit due to increased real wages and lower prices among incumbent bank borrowers.

In contrast, reducing bond issuance costs boosts the size and profitability of mid-size firms that switch from bank borrowing to bond issuance, while forcing out the smallest firms at the low end of the efficiency spectrum. The largest firms and the smallest surviving firms (non-switchers) 
experience a small drop in output. The end result is an increase in the real wage, consumption, and welfare. Mid-size firms are the biggest "winners" from decreasing bond issuance costs, as large incumbent issuers find the surplus from reduced issuance fees eroded by increased labor costs. This general equilibrium effect is new to both macroeconomics and finance.

Whether one policy produces a greater welfare increase than another depends on the relative size of transactions costs in the two credit markets. Welfare gains from increasing banking sector efficiency are greatest when the fixed costs of bond issuance are high, so that more firms - and larger firms, on average - are dependent on bank credit even before the change and enjoy a reduction in marginal costs when the interest rate on their loans falls. Welfare gains from reducing the cost of bond issuance are largest when monitoring costs in the banking sector are very high for two reasons. First, the switch to bond issues generates an even greater savings in the marginal cost of capital, so the switching has a bigger impact on prices than in the case where monitoring costs are low. As a second-order effect, the bigger punch to prices provides an extra boost to the real wage, causing more exit. The extra exit occurs at the bottom of the efficiency spectrum, increasing aggregate productivity at the same time the switchers are enjoying big savings on their marginal cost of capital financing.

There are a number of ways to expand the model in future research. Among them, we model the banking sector here as perfectly competitive. Modeling imperfect competition among banks using a Salop-Hotelling approach would introduce an interdependence between the size of the banking sector and the interest rate charged on bank loans. A similar feature could be modeled for underwriters in the bond market. The transactions costs could become a function of both policy and competition within and between financial sectors. The model could be extended to incorporate bank reserves as a mechanism for monetary policy, as in Bernanke and Blinder (1988, 1992). It could also contain a limited participation dimension in the bond market to capture potential differences in the depth of credit instruments in the banking sector versus the bond market. We have abstracted from any correlation between the risk of default and firm size, as discussed above. However, the riskiness of each firm could depend explicitly on its capital structure, which obviously varies across firms in our framework and likely varies across the business cycle. To the degree that default rates and monitoring costs vary with the business cycle, bank and bond spreads could be allowed to do so also. Any of these additional mechanisms could impact firms' choice of financial instrument and intra- 
industry reallocation following changes in the structure of transactions costs in financial markets. Nonetheless, our key insight - that changes in transactions costs in a particular credit market will impact the pattern of intra-industry reallocation and macroeconomic outcomes differently, depending on the underlying level of financial development and which market one targets - remains unchallenged by such extensions. 


\section{References}

Altman, E. I., And H. J. Suggitt (2000): "Default rates in the syndicated bank loan market: A mortality analysis," The Journal of Banking and Finance, 24(1-2), 229-253.

Asarnow, E., And D. Edwards (1995): "Measuring Loss on Defaulted Bank Loans: A 24-Year Study," Journal of Commercial Lending, 77(7), 11-23.

Beck, T., A. DemirgüÇ-Kunt, L. Laeven, and R. Levine (2008): "Finance, Firm Size, and Growth," Journal of Money, Credit, and Banking, 40(7), 1379-1405.

Benfratello, L., F. Schiantarelli, and A. Sembenelli (2008): "Banks and innovation: Microeconometric evidence on Italian firms," Journal of Financial Economics, 90(2), 197-217.

Bernanke, B. S., And A. S. Blinder (1988): "Credit, Money, and Aggregate Demand," The American Economic Review, 78(2), 435-439.

(1992): "The Federal Funds Rate and the Channels of Monetary Transmission," The American Economic Review, 82(4), 901-921.

Broda, C., And D. E. Weinstein (2006): "Globalization and the Gains from Variety," The Quarterly Journal of Economics, 121(2), 541-585.

Carlstrom, C. T., and T. S. Fuerst (1997): "Agency Costs, Net Worth, and Business Fluctuations: A Computable General Equilibrium Analysis," The American Economic Review, 87(5), 893-910.

(2001): "Monetary shocks, agency costs, and business cycles," Carnegie-Rochester Conference Series on Public Policy, 54(1), $1-27$.

Claessens, S., and L. Laeven (2004): "What Drives Bank Competition?," Journal of Money, Credit, and Banking, 36(3), 563-583.

DE Blas, B., AND K. N. Russ (2009): "FDI in the Banking Sector," Manuscript, University of California, Davis. 
De Fiore, F., And H. Uhlig (2005): "Bank Finance versus Bond Finance: What Explains the Differences between US and Europe?," Working Paper 547, European Central Bank.

DemirgüÇ-Kunt, A., And V. Maksimovic (2002): "Funding growth in bank-based and marketbased financial systems: evidence from firm-level data," Journal of Financial Economics, 65(3), $337-363$.

Denis, D. J., And V. T. Mihov (2003): "The choice among bank debt, non-bank private debt, and public debt: evidence from new corporate borrowings," Journal of Financial Economics, $70(1), 3-28$.

Dermine, J., and C. N. De Carvalho (2006): "Bank Loan Losses-Given-Default, a Case Study," The Journal of Banking and Finance, 30(4), 1219-1243.

DeYoung, R., and T. Rice (2006): "Erratum: Noninterest Income and Financial Performance at U.S. Commercial Banks," The Financial Review, 41(3), 449-450.

Diamond, D. W. (1991): "Monitoring and Reputation: The Choice between Bank Loans and Directly Placed Debt," Journal of Political Economy, 99(4), 689-721.

Endo, T. (2008): "Broadening the offering choice of corporate bonds in emerging markets: Costeffective access to debt capital," Policy Research Working Paper 4655, The World Bank.

Feenstra, R. C. (1994): "New Product Varieties and the Measurement of International Prices," The American Economic Review, 84(1), 157-177.

Fisher, T. C. G., and J. Martel (2008): "Empirical Evidence on the Efficiency Cost of a Debtor-Friendly Bankruptcy System," Working paper, SSRN.

Ghironi, F., And K. K. Lewis (2008): "Stock Market Listing and Business Cycles with Heterogeneous Firms," Manuscript, Boston College.

Ghironi, F., And M. J. Melitz (2005): "International Trade and Macroeconomic Dynamics with Heterogeneous Firms," The Quarterly Journal of Economics, 120, 381-411.

Glennon, D., And P. J. Nigro (2005): "Measuring the Default Risk of Small Business Loans: A Survival Analysis Approach," Journal of Money, Credit, and Banking, 37(5), 923-947. 
Greenwood, J., Z. Hercowitz, and G. M. Huffman (1988): "Investment, Capacity Utilization, and the Real Business Cycle," The American Economic Review, 78(3), 402-417.

Gupton, G. M., D. Gates, and L. V. Carty (2000): "Bank-Loan Loss Given Default," Moody's Investors Service Special Comment.

Hale, G. B., And J. Santos (2008): "The Decision to First Enter the Public Bond Market: The Role of Firm Reputation, Funding Choices, \& Bank relationships," The Journal of Banking and Finance, 32(9), 1928-40.

Helpman, E., M. J. Melitz, and S. R. Yeaple (2004): "Export versus FDI with Heterogeneous Firms," The American Economic Review, 94(1), 300-316.

Holmstrom, B., and J. Tirole (1997): "Financial Intermediation, Loanable Funds, and the Real Sector," The Quarterly Journal of Economics, 112(3), 663-691.

Houston, J., And C. James (1996): "Bank Information Monopolies and the Mix of Private and Public Debt Claims," Journal of Finance, 51(5), 1863-1889.

Hurt, L., And A. Felsovalyi (1998): "Measuring Loss on Latin American Defaulted Bank Loans: A 27-Year Study of 27 Countries," Journal of Lending 83 Credit Risk Management, 81(2), 41-46.

Jakubík, P., And J. Seidler (2009): "Implied Market Loss Given Default in the Czech Republic Structural-Model Approach," Czech Journal of Economics and Finance, 59(1), 20-40.

Johnson, S. A. (1997): "An Empirical Analysis of the Determinants of Corporate Debt Ownership Structure," Journal of Financial and Quantitative Analysis, 32(1), 47-69.

Krishnaswami, S., P. A. Spindt, and V. Subramaniam (1999): "Information asymmetry, monitoring, and the placement structure of corporate debt," Journal of Financial Economics, $51(3), 407-434$.

La Porta, R., F. Lopez-de Silanes, and G. Zamarripa (2003): "Related Lending," The Quarterly Journal of Economics, 118(1), 231-268. 
Leal, R. P., and A. L. Carvalho-da Silva (2006): "The Development of the Brazilian Bond Market," Latin american and caribbean research network working paper, Inter-Americal Development Bank, Abbreviated version published in Bond Markets in Latin America: On the Verge of a Big Bang?, eds. Borensztein, E., Cowan, K., Eichengreen, B., and Panizza, U. Cambridge, MA: MIT Press, 2008.

Levine, R. (1997): "Financial Development and Economic Growth: Views and Agenda," Journal of Economic Literature, 35, 688-726.

(2005): "Finance and Growth: Theory and Evidence," in Handbook of Economic Growth, ed. by P. Aghion, and S. Durlauf, vol. 1A of Handbooks in Economics, chap. 12, pp. 865-934. North-Holland Publishing Company.

Maltby, E. (2009): "Small biz loan failure rate hits 12\%," CNNMoney.com.

Melitz, M. J. (2003): "The Impact of Trade on Intra-Industry Reallocations and Aggregate Industry Productivity," Econometrica, 71(6), 1695-1725.

Mizen, P., And S. Tsoukas (2008): "What Effect Has Bond Market Development in Emerging Asia Had on the Issue of Corporate Bonds?," Working Paper, University of Nottingham.

Ong, L. L., and P. Luengnaruemitchai (2005): “An Anatomy of Corporate Bond Markets: Growing Pains and Knowledge Gains," Working Paper 05-152, International Monetary Fund.

Repullo, R., And J. Suarez (1998): "Monitoring, Liquidation, and Security Design," The Review of Financial Studies, 11, 163-187.

(2000): "Entrepreneurial Moral Hazard and Bank Monitoring: A model of the credit channel," European Economic Review, 44, 1931-1950.

Schuermann, T. (2004): "What Do We Know About Loss Given Default?," Working Paper 04-01, Wharton Financial Institutions Center.

Sophastienphong, K., Y. Mu, and C. Saporito (2008): South Asian bond markets: Developing long-term finance for growth. The World Bank. 
Thorburn, K. S. (2000): "Bankruptcy Auctions: Costs, Debt Recovery, and Firm Survival," Journal of Financial Economics, 58(3), 337-368.

Townsend, R. M. (1979): "Optimal Contracts and Competitive Markets with Costly State Verification," Journal of Economic Theory, 21(2), 265-293.

Xinhua (2009): "S Korea's bank loan default rate declines to 6-month low in June," Global Times.

Zervos, S. (2004): "The transactions costs of primary market issuance: The case of Brazil, Chile, and Mexico," Policy Research Working Paper WPS 3424, The World Bank, Washington, DC. 


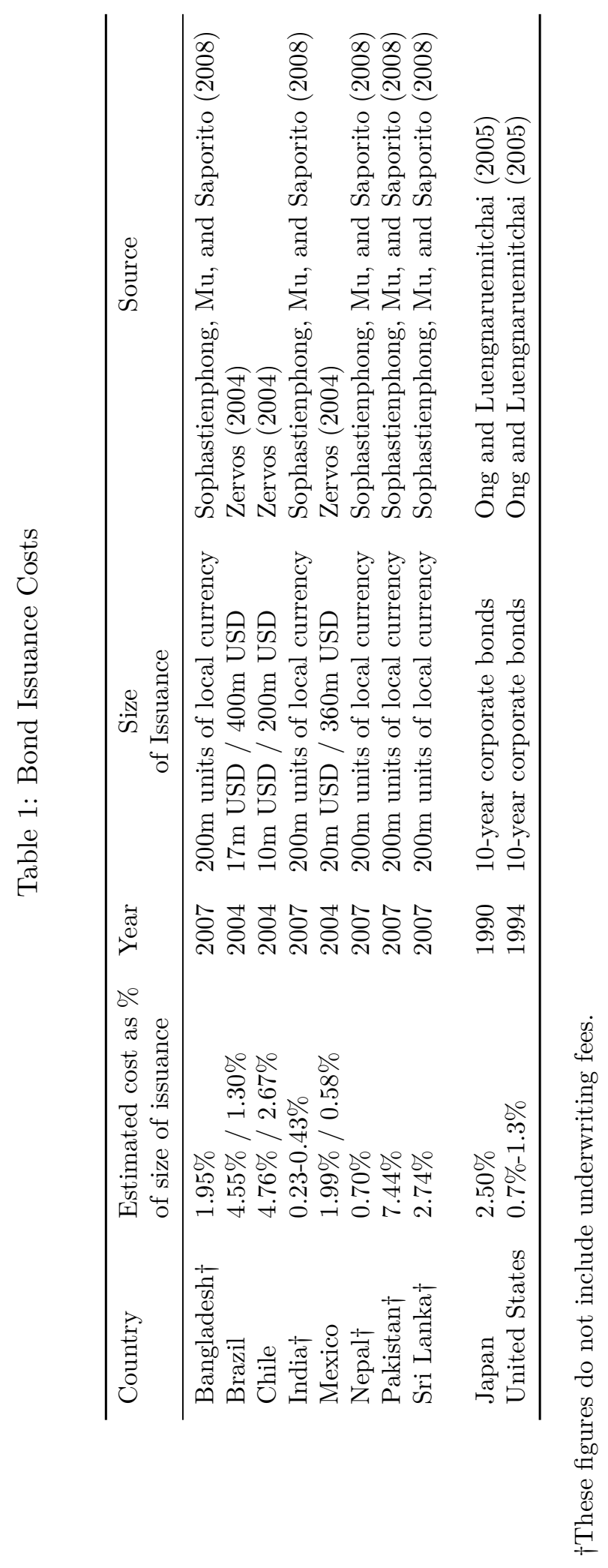




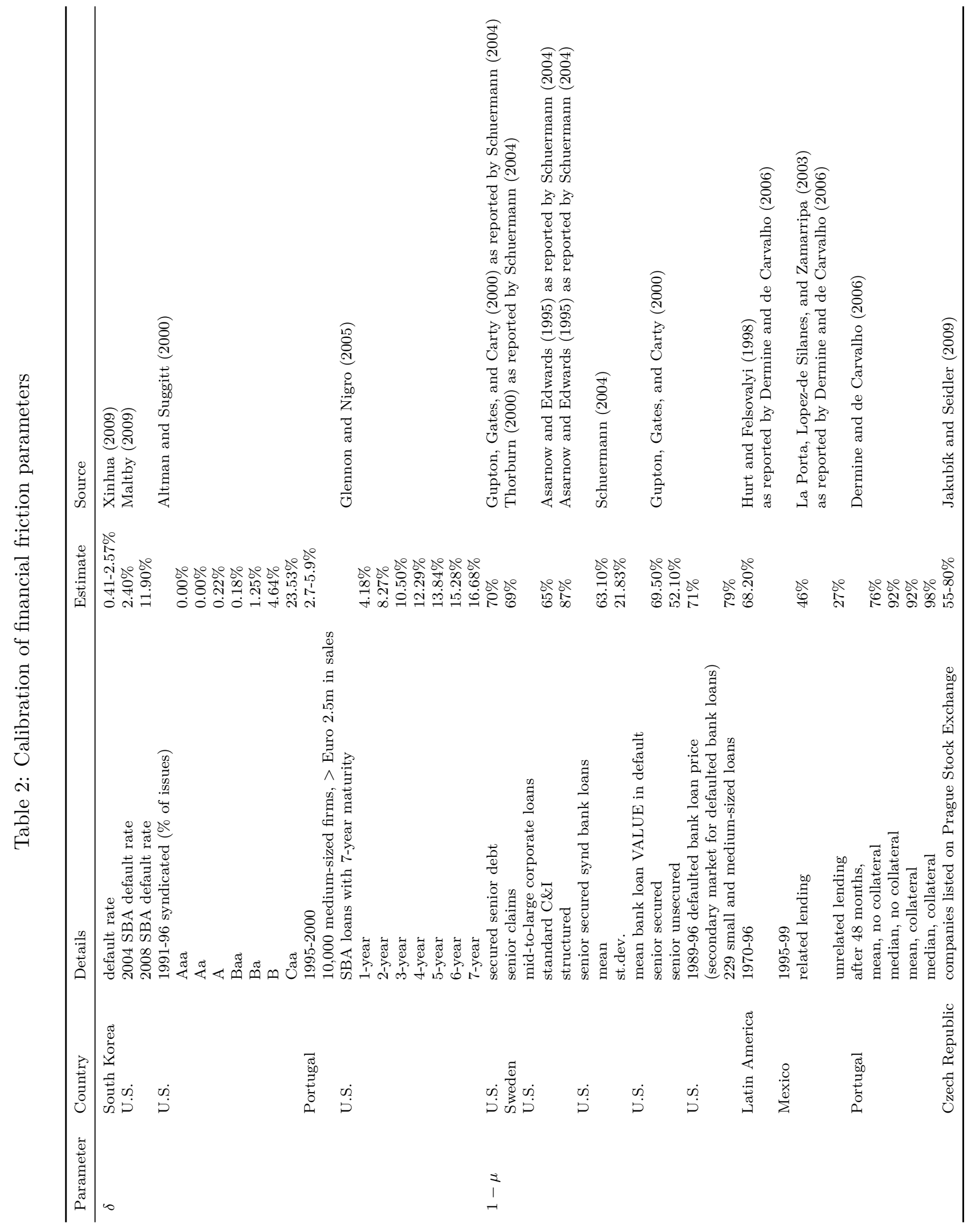




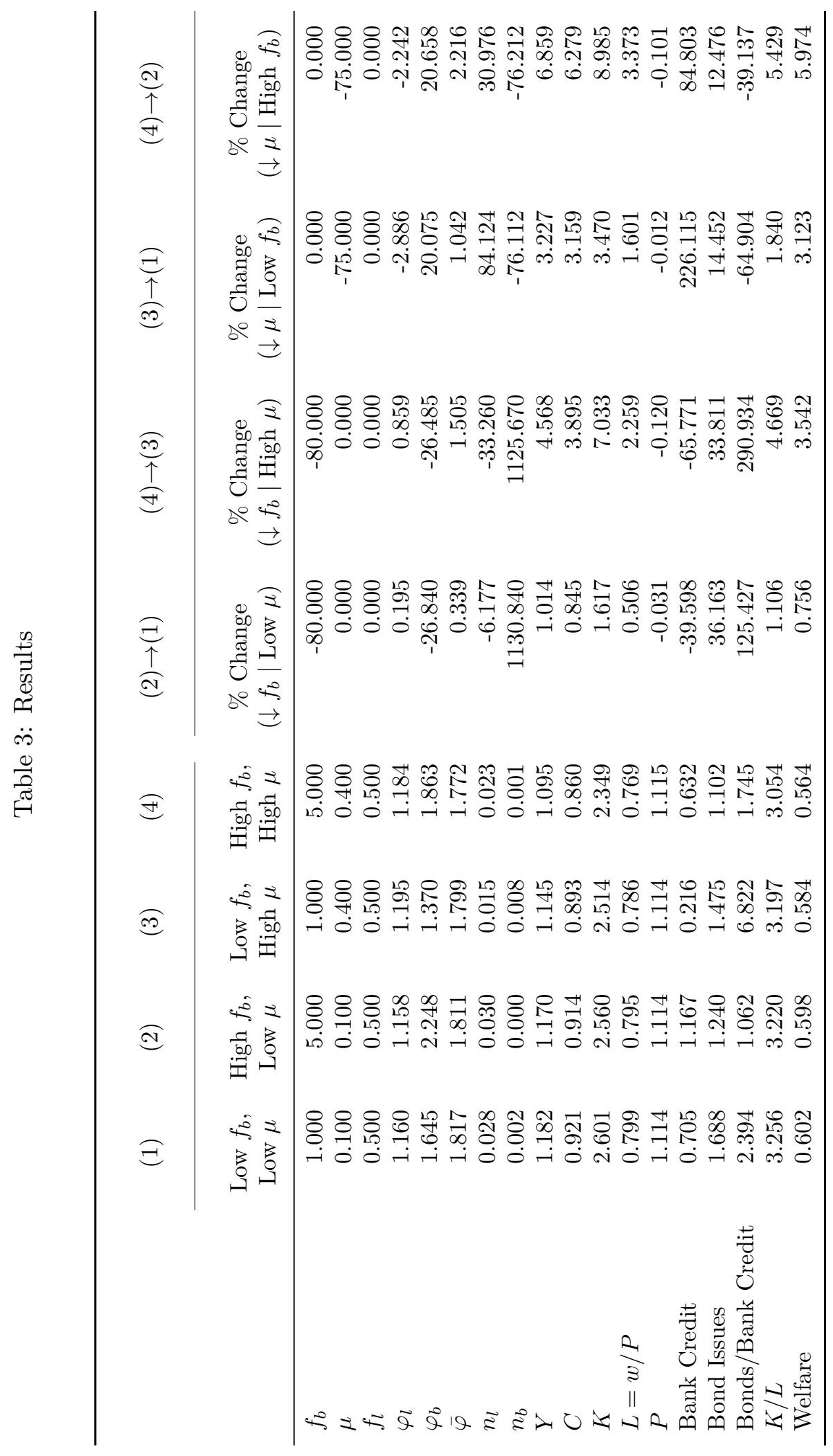

